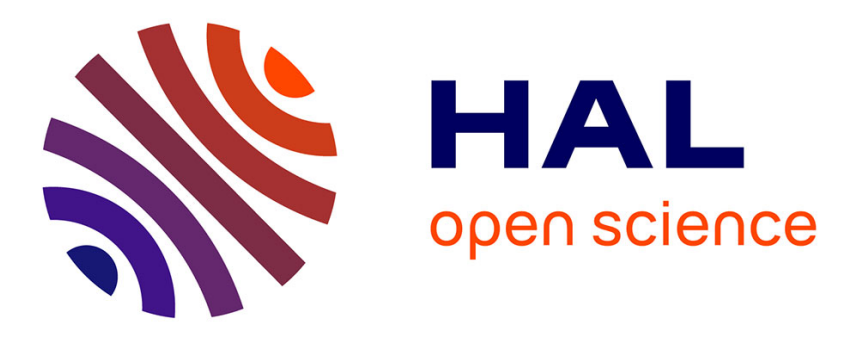

\title{
Can stable isotopes quantify soil carbon build-up from organic fertilizers?
}

Floriane Jamoteau, Jérôme Balesdent, Isabelle Basile-Doelsch, Emmanuel Tillard, Antoine Versini

\section{- To cite this version:}

Floriane Jamoteau, Jérôme Balesdent, Isabelle Basile-Doelsch, Emmanuel Tillard, Antoine Versini. Can stable isotopes quantify soil carbon build-up from organic fertilizers?. Isotopes in Environmental and Health Studies, 2021, 57 (5), pp.470-491. 10.1080/10256016.2021.1946532 . hal-03534249

\author{
HAL Id: hal-03534249 \\ https://hal.science/hal-03534249
}

Submitted on 19 Jan 2022

HAL is a multi-disciplinary open access archive for the deposit and dissemination of scientific research documents, whether they are published or not. The documents may come from teaching and research institutions in France or abroad, or from public or private research centers.
L'archive ouverte pluridisciplinaire HAL, est destinée au dépôt et à la diffusion de documents scientifiques de niveau recherche, publiés ou non, émanant des établissements d'enseignement et de recherche français ou étrangers, des laboratoires publics ou privés. 


\section{Can stable isotopes quantify soil carbon build-up from organic fertilizers?}

2 Floriane Jamoteau ${ }^{\text {abc*, Jérôme Balesdent }}{ }^{\mathrm{c} \tau}$, Isabelle Basile-Doeslch ${ }^{\mathrm{c}}$, Emmanuel

3 Tillard $^{\text {de }}$, Antoine Versini ${ }^{\mathrm{ab}}$

$4{ }^{a}$ CIRAD, Internal Research Unit (UPR) Recycling and Risk, Station de La Bretagne, 97743 Saint-

5 Denis, Réunion, France; ${ }^{b}$ Internal Research Unit (UPR) Recycling and Risk, Université de

6 Montpellier, CIRAD, Montpellier, France; ${ }^{c}$ CEREGE, Aix-Marseille Université, CNRS, IRD, Collège

7 de France, INRA, F-13545 Aix-en-Provence, France; ${ }^{d}$ CIRAD, Joint Research Unit (UMR)

8 Mediterranean and Tropical Livestock Systems, 97410 Saint-Pierre, Réunion, France; ${ }^{e}$ Joint Research

9 Unit (UMR) Mediterranean and Tropical Livestock Systems, Université de Montpellier, CIRAD,

10 Montpellier, France

$11 *$ Corresponding author: jamoteau@cerege.fr

$12{ }^{\tau}$ deceased, 19 July 2020

13 Word count of the whole paper (with figures, tables and additional information): 9376 words. 
Application of organic fertilizers (OF) can supply carbon (C) to the soil in crop fields. OF-derived $\mathrm{C}(\mathrm{OF}-\mathrm{C})$ is often estimated using the differential method that can be biased due to indirect effects of OF on soil C. This study tested three methods to quantify OFC: (i) the widespread differential method, (ii) the synchronic isotopic method comparing plots with and without OF and (iii) the asynchronic isotopic method mimicking a trial without a control plot. These methods were implemented on an Arenosol and an Andosol supplied during 13 years with slurry or compost. The results highlighted the relevance of using the isotopic synchronic method, which focuses on the direct effect of OFs on the soil organic matter (without bias of vegetation change) and considers control soil's evolution. Considering limit of resolution in the Arenosol, the method was suitable after 4 years of fertilisation for an initial $\delta^{13} \mathrm{C}$ difference of $7.5 \%$ between OF and soil, and after 9 years for a difference of $3.5 \%$. A sensitivity analysis showed that particular attention must be paid to $\mathrm{OF}-\delta^{13} \mathrm{C}$ variability to guarantee the method validity. The method proved to be suitable to study the factors controlling the OF-C fate in tropical soils.

Keywords: carbon, carbon stable isotopes, ${ }^{13} \mathrm{C}$, organic fertilizers, Arenosol, Andosol

\section{Introduction}

Ensuring high organic carbon contents in agricultural soils appears to be an effective way of meeting the triple challenge of food security, adaptation to climate change and mitigation of anthropogenic emissions (4p1000 initiative, [1]). Organic fertilizationcurrently encouraged by the development of the circular economy-is a key means of increasing organic $\mathrm{C}$ stocks in agricultural soils. In agroecosystems benefitting from organic fertilizer $(\mathrm{OF})$ amendments, there are three main sources of soil organic $\mathrm{C}$ (Figure 1): (1) native soil organic matter (SOM) (derived from $\mathrm{C}$ inputs preceding organic fertilization; initial-C), (2) carbon derived from crops (via aboveground and belowground C inputs provided by crops; crop-C), and (3) carbon from OFs (OF-C).

Carbon isotope methods using ${ }^{14} \mathrm{C}$ isotopes [2], [3] or stable ${ }^{13} \mathrm{C}$ isotopes [4]-[6] help track the fate of $\mathrm{C}$ in various ecosystems. There are natural variations in the ${ }^{13} \mathrm{C} /{ }^{12} \mathrm{C}$ ratio according 
to the photosynthesis pattern in two types of plants: $\mathrm{C}_{3}$-plants with a $\delta^{13} \mathrm{C}$ value in the -29 to $25 \%$ range, and $\mathrm{C}_{4}$-plants with a $\delta^{13} \mathrm{C}$ value in the -16 to $-12 \%$ range [7], [8] . Theses natural $\delta^{13} \mathrm{C}$ variations can also be attributed to various factors as stomata regulation by microclimate or nitrogen availability [9], [10] or carbon gain from mycorrhizal fungi [11][13]. $\delta^{13} \mathrm{C}$ has been used to quantify carbon changes throughout soil profiles, leading to a $\mathrm{C}$ age distribution to $1 \mathrm{~m}$ depth [14], but also on various soil components and soil fractions [15]-[17]. Quantification of OF-C contribution is generally calculated by a stock difference or comparison: the $\mathrm{C}$ stock in the control soil at a given depth (often $0-30 \mathrm{~cm}$ ) is subtracted from the $\mathrm{C}$ stock in the fetilized soil at an equivalent depth [18]-[21]. But the C-stock difference does not take into account the effect of OFs on native SOM mineralization rates (i.e. so-called priming effect) neither crop-C inputs if vegetation's changes occurred [22], [23]. In the same way that isotopic mass budget are used to trace $\mathrm{C} 3 / \mathrm{C} 4$ vegetation changes, $\delta^{13} \mathrm{C}$ can be used to monitor long-term carbon inputs and OF impacts on soil carbon [8], [24]-[27]. However, isotopic mixing budgets can be applied only if the isotopic resolution limit is reached (i.e there is a statistical significant difference between isotopic signatures of the end-members) and if the sensitivity of the different parameters of the isotopic equation is analysed [8].

Several studies that have quantified OF-C using the isotopic method are summarized in Table 1 as a function of the experimental duration and sampling frequency. Short-term experiments (up to 120 days) have been carried out using field experimental designs [28]-[31] as well as in mesocosms ( through $\delta^{13} \mathrm{C}$ of $\mathrm{CO}_{2}$ ) [32], [33]. Two stages of decomposition processes were observed over time [32], [30]: a first stage corresponding to the biodegradation of a readily available and more liquid phase accumulated over time in the upper soil; a second phase, $48 \mathrm{~h}$ after OF amendment, corresponded to the biodegradation of the slurry solid phase [30]. 
[37]. All of them, except Nicoloso et al., 2018 [37], focused on a temperate climatic zone. Long-term single quantification experiments have been conducted over 1 year [38], 25 years [37] and 42 years [39]. However, single quantification did not reveal temporal changes in soil C dynamics over time. Long-term chronosequence experiments have also been carried out [34]-[36]. Kristiansen et al. (2005) [35] and Thomsen and Christensen (2010) [36] used aboveground fresh maize biomass and sheep faeces to amend four Danish fields (including an Alfisol Hapludalf and an Inceptisol Orchrept) over periods of 9 and 14 years, respectively (with total input of 32,000 to 51,100 kg C.ha ${ }^{-1}$ ). Gerzabek et al., 1997 [34] applied animal manure on a Swedish Eutric Cambisol over 42 years (with total input of $84000 \mathrm{~kg} \mathrm{C}^{-h^{-1}}$ ) (Table 1). These studies showed: (1) that $\mathrm{OF}-\delta^{13} \mathrm{C}$ may vary in long-term experiments [34], and (2) that $\mathrm{C}$ derived from OFs and vegetation had jointly contributed $13-55 \%$ of the soil $\mathrm{C}$ at the end of the experiments [34]-[36].

To the best of our knowledge, no long-term chronosequence studies involving the ${ }^{13} \mathrm{C} /{ }^{12} \mathrm{C}$ isotopic proxy have been performed in tropical or subtropical environments to track the fate of OF-C in soils. Natural variations in ${ }^{13} \mathrm{C}$ are highly prevalent in tropical areas under $\mathrm{C}_{3}$ forests and $\mathrm{C}_{4}$ crops. As mineralization and degradation processes are faster in tropical conditions, the isotopic method should be relevant for studying long-term dynamics of OF-C incorporation into tropical soils. A 13-year grassland trial was conducted on an Arenosol and on an Andosol with repeated fertilization using slurry and compost in a tropical area (Réunion, France). We tested the applicability of the ${ }^{13} \mathrm{C}$ isotopic method for quantifying soil $\mathrm{C}$ inputs through long-term $\mathrm{OF}$ amendments in tropical soils. Tree quantification methods were tested in this study: (1) the widespread differential method; (2) the isotopic budget in a synchronous calculation system with a comparison of amended and unamended control plots (the synchronic method) and (3) the isotopic budget in an asynchronous system with amended plots and plots at the start of the experiment (asynchronic method, experimental 
design without control plots).

\section{Material and methods}

\subsection{Study sites}

The experiment was conducted on the volcanic island of Réunion (Indian Ocean) on two different soils [40]: (1) an Arenosol, i.e. a typically sandy soil located in the southwestern part

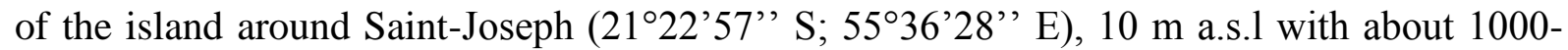
$1500 \mathrm{~mm}$ rainfall and mean annual temperature of $23.3^{\circ} \mathrm{C}$. The soil was under Chloris, Paspalum and Panicum cover ( $\mathrm{C}_{4}$-plants); (2) an Andosol, i.e. a soil containing allophanes which are nanometric aluminosilicates resulting from the alteration of volcanic glasses,

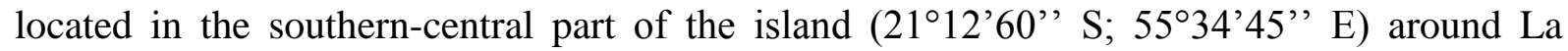
Plaine des Cafres, 1,600 m a.s.l with about 1500 to $2000 \mathrm{~mm}$ rainfall and a mean annual temperature of $14.2^{\circ} \mathrm{C}$. The soil was under Festuca, Dactylis and Bromus cover $\left(\mathrm{C}_{3}\right.$-plants).

\subsection{Experimental design}

For both sites, the experimental design included three different fertilization treatments applied from 2005 to 2017 and repeated in three block. Plots measured $3.6 \mathrm{~m}^{2}$ and were separated by $0.3 \mathrm{~m}$ wide edge strips (Figure $\mathrm{S} 1$ ). The composition of the three treatments were: bovine manure compost and bovine slurry as two OF treatments and mineral fertilization as control treatment. For convenience, bovine manure compost and bovine slurry are respectively called compost and slurry hereafter. OFs were applied on plots when pastures were harvested (6-8 times per year). OF inputs were estimated at around 9,060 kg C.ha. ${ }^{-1} \mathrm{yr}^{-1}$ for bovine manure compost and 19,760 kg C.ha ${ }^{-1} \mathrm{yr}^{-1}$ for bovine slurry (considering a mean of seven applications). The same amount of the same OF was applied at both sites (Table 2). Mineral fertilization consisted of $120 \mathrm{~kg}$ of mineral N. No carbon was added in this mineral fertilization modality so these plots were considered as controls in the isotopic calculations. C 
117 in control plot soils thus included $\mathrm{C}$ from the initial SOM and C input from vegetation

118 throughout the experiment (Figure 1).

\subsection{Soils and organic fertilizers sampling}

Amended soils and control soils were sampled yearly from years 3 to 13 (experiment started at year 0, i.e. 2004) for the Arenosol and from years 1 to 13 for the Andosol. The top $15 \mathrm{~cm}$ of soil was sampled with an auger in November or October each year before OF application. OFs were sampled yearly from years 2 to 9 . Soils and $\mathrm{OF}$ were dried at $60^{\circ} \mathrm{C}$ and sieved to $2 \mathrm{~mm}$ before storage at $20^{\circ} \mathrm{C}$. Subsamples $(5 \mathrm{~g})$ were dried and ground in a mixer mill (MM400, Retsch) to ensure the overall representativeness of the analyzed samples.

As there was an insufficient quantity of remaining soil, control plot samples were not analysed from the Arenosol block 1 in year 3, from the Andosol block 3 in year 10 and control plots from the three Andosol blocks in year 2.

\subsection{C analyses and $C$ stock calculations}

The carbon content was measured in air dried samples using elemental analyzer isotopic ratio mass spectrometry (Flash EA 1112 Series and ThermoFinnigan DELTAplus IRMS). 10$20 \mathrm{mg}$ and 3-6 mg samples were analysed for the Arenosol and the Andosol, respectively. IAEA-CH-6 was used as a control of the measurement accuracy and IAEA-CH-7 as an international lab standard [41]. Analysed soil humidity ranged about $1.7 \%$ on the Arenosol and $8.9 \%$ on the Andosol (dried at $105^{\circ} \mathrm{C}$ ). Thus, a carbon content correction link to residual water were perform following the $\mathrm{C}$ analysis

139 where $S$ is the stock in $\mathrm{kg} \mathrm{C} \cdot \mathrm{m}^{-2}, \rho$ is the bulk density in $\mathrm{g} \cdot \mathrm{cm}^{-3}, e$ is the soil thickness $(0.15 \mathrm{~m})$ 


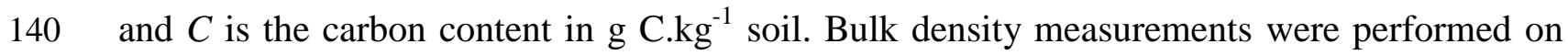

141 the Arenosol $(5-10 \mathrm{~cm})$ in year 0 and year 14 and on the Andosol $(0-10 \mathrm{~cm})$ in year 3 and year

142 16. We used the Alexander law to estimate the bulk density over time (equation 2, Figure S2,

143 [42]). Alexander coefficients underwent least squares adjustment on carbon linear regression

144 data, by fitting both measured values in each soils.

$$
\rho=A_{\text {coef }}-A_{\text {slope }} * \sqrt{C}
$$

146 with $A_{\text {coef }}$ Alexander coefficient, $A_{\text {slope }}$ the Alexander slope and $C$ the total carbon content in

$147 \mathrm{gC} . \mathrm{kg}^{-1}$ soil. The bulk density data are given in Figure S2.

\section{$2.5 \delta 13 C$ analysis and $\triangle \delta 13 C$ calculations}

$\delta^{13} \mathrm{C}$ Isotope measurements were done using the same elemental analyzer isotopic ratio mass spectrometry procedure as for the carbon content analysis. IAEA-CH-6 (-10.5 \%o) was used for calibration and IAEA-CH-7 as measurement of precision (control yielded as mean of $-32.15 \pm-0.15 \%$ ) [41]. $\delta^{13} \mathrm{C}$ was calculated as follows:

$\delta^{13} C(\%)=\left(\frac{\left(\frac{13 C}{12 C}\right)_{\text {sample }}}{\left(\frac{13 C}{12 C}\right)_{\text {reference }}}-1\right) * 1000$

154 VPDB was used as reference standard for $\delta^{13} \mathrm{C}$ units.

$155 \Delta \delta^{13} C$ is the difference between initial $\delta^{13} \mathrm{C}$ of control plots at year $0\left(\delta^{13} C_{C T L s o i l T 0}\right.$, CTL stands

156 for control) and vegetation $\delta^{13} \mathrm{C}\left(\delta^{13} C_{\text {veg }}\right)$ or difference between $\delta^{13} C_{C T L s o i l T O}$ and $\mathrm{OF}-\delta^{13} \mathrm{C}$

$157\left(\delta^{13} C_{O F}\right)$ such as:

$158 \Delta \delta^{13} C(\%)=\mid \delta^{13} C_{\text {CTLSoilto }}-\delta^{13} C_{\text {veg }}$ or $\delta^{13} C_{O F} \mid$

160 Three methods for quantifying OF-C were tested in this study: the differential method (the 
most common), the synchronic isotopic method and the asynchronic isotopic method.

\subsubsection{Differential method}

163 The differential method estimates the proportion of OF-derived carbon $\left(f_{C O F}\right.$, equation 5) by

164 dividing the OF-C $\left(\mathrm{C}_{\text {OFsoil }}-C_{\text {CTLsoil }}\right)$ by the total carbon of the amended plots $\left(\mathrm{C}_{\text {OFsoil }}\right)$.

$165 f_{\text {COF }}=\frac{C_{\text {OFsoil }}-C_{\text {CTLSoil }}}{C_{\text {OFsoil }}}$

166 The carbon stock $\left(\mathrm{kgC} \cdot \mathrm{ha}^{-1}\right.$ in $\left.0-15 \mathrm{~cm}\right)$ derived from OF $\left(S_{C O F}\right)$ was calculated with equation

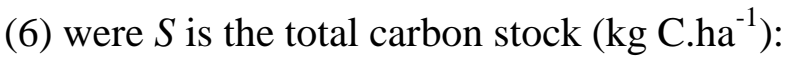

$S_{C O F}=S * f_{C O F}$

\subsubsection{Synchronic isotopic method} years 2 and 10 in block 3 for the Andosol. The calculation of $f_{C O F}$ was therefore not possible

In the synchronic isotopic method, the proportion of OF-derived $\mathrm{C}$ was calculated using the mixing model (7) (adapted from Balesdent et al., 1987 [4] ):

$$
f_{C O F}=\frac{\delta^{13} C_{O F s o i l}-\delta^{13} C_{C T L S o i l}}{\delta^{13} C_{O F}-\delta^{13} C_{C T L s o i l}}
$$

where $f_{C O F}$ is the proportion of OF-C, $\delta^{13} C_{O F s o i l}$ is the isotopic signature of the amended soil, $\delta^{13} C_{C T L s o i l}$ is the isotopic signature of soil under mineral fertilization and $\delta^{13} C_{O F}$ is the isotopic signature of the applied OF. By this synchronic method, $f_{C O F}$ was estimated on a yearly basis, with the same sampling year of $\delta^{13} C_{C T L s o i l}$ and $\delta^{13} C_{O F s o i l . ~}$ The carbon stock (kg C.ha ${ }^{-1}$ in 0-15 $\mathrm{cm})$ derived from $\mathrm{OF}\left(S_{C O F}\right)$ was calculated with equation 6. for those years. 
In the asynchronic isotopic method, the proportion of OF-derived $\mathrm{C}$ was calculated by the mixing model (8) (adapted from Balesdent et al., 1987) :

$$
f_{\text {COF }}=\frac{\delta^{13} C_{\text {OFsoil }}-\delta^{13} C_{C T L s o i l T 0}}{\delta^{13} C_{O F}-\delta^{13} C_{C T L s o i l T 0}}
$$

where $f_{C O F}$ is the proportion of OF-C, $\delta^{13} C_{O F s o i l}$ is the isotopic signature of amended soil, $\delta^{13} C_{C T L s o i l T O}$ is the isotopic signature of soil under mineral fertilization at year 0 and $\delta^{13} C_{O F}$ is the isotopic signature of the applied OF.

Samples from year 0 were missing, so we estimated the $\delta^{13} C_{C T L s o i l T O}$ of each plot using linear regressions (Figure 2). We performed a linear regression whereby all control plots for a given soil type were considered and kept the same slope but change the initial $\delta^{13} \mathrm{C}$ of year 0 block wise (Figure 2). Each control plot thus had its own $\delta^{13} \mathrm{C}$ estimation over time with linear regression being applied to reduce experimental variation (see Discussion part 4.1.2). The carbon stock $\left(\mathrm{kgC}_{\mathrm{Cha}}{ }^{-1}\right.$ in $\left.0-15 \mathrm{~cm}\right)$ derived from $\mathrm{OF}\left(S_{C O F}\right)$ was calculated with equation 6.

\subsection{Statistical analysis and overcoming block effect}

All statistical analyses were performed with $l m$ and $t$.test functions of the R software package differential method, between $\delta^{13} \mathrm{C}_{\mathrm{CTLsoil}}$ and $\delta^{13} \mathrm{C}_{\mathrm{OFsoil}}$ for the isotopic method and between $\delta^{13} \mathrm{C}_{\mathrm{CTL} \text { soilTo }}$ and $\delta^{13} \mathrm{C}_{\mathrm{OFsoil}}$ for the asynchronic isotopic method. T-test between $\delta^{13} \mathrm{C}_{\mathrm{CTLsoil}}$ and $\delta^{13} \mathrm{C}_{\mathrm{OF}}$ were performed to discuss resolution and sensitivity analysis for isotopic methods (see part 4.2).

\subsection{Sensitivity analysis of the isotope mixing equation}

We ranked the impact of each variable of the mixing equation 7 . We first determined the 
percentage deviation from the mean (standard deviation divided by the mean on T13) for the

206 three parameters: $\delta^{13} \mathrm{C}_{\mathrm{OFsoil}}, \delta^{13} \mathrm{C}_{\mathrm{CTRLsoil}}$ and $\delta^{13} \mathrm{C}_{\mathrm{OF}}$. Then we carried out a random selection of 1000 values for the three variables according to the deviation percentage calculated in T13. Using equation 7, $1000 f_{C O F}$ values were thus obtained for the Arenosol compost, Arenosol slurry and Andosol compost treatments.

The weight of each variable in the mixing equation was obtained thanks to the anova function in the $\mathrm{R}$ software package ( $\mathrm{R}$ Core Team, 2016), using the 3x1000 random variables from $\delta^{13} \mathrm{C}_{\mathrm{OFsoil}}, \delta^{13} \mathrm{C}_{\mathrm{CTRLsoil}}$ and $\delta^{13} \mathrm{C}_{\mathrm{OF}}$ and the $\log \left(f_{\mathrm{COF}}\right)$.

\section{Results}

\subsection{Control soil C content and $\delta^{13} C$}

The organic carbon content in Arenosol control plots (under mineralization) increased from $10.5 \pm 0.0$ g. $\mathrm{kg}^{-1}$ in year 3 to $17.9 \pm 1.8 \mathrm{~g} \cdot \mathrm{kg}^{-1}$ in year 13 . The control plots $\delta^{13} \mathrm{C}$ (Figure 2a) increased over time. According to linear regressions, $\delta^{13} \mathrm{C}$ increased from $-18.2 \%$ to $-16.8 \%$ o in block 1 , from $-17.0 \%$ o to $-15.6 \%$ in block 2 and from $-17.0 \%$ o to $-15.5 \%$ in block 3 . The Arenosol controls showed the same overall variation pattern over time but with a slight shift in the initial value for estimated year 0 . Including all block, the $\delta^{13} \mathrm{C}$ from year $0(-18.2$ to -17 \%o) indicated that the organic matter content was from mixed $\mathrm{C}_{3}$ and $\mathrm{C}_{4}$ origins, with a predominance of $\mathrm{C}_{4}$. Vegetation $\delta^{13} \mathrm{C}$ in this Arenosol trial was about -13.9 \%o (Table 2).

The organic carbon content in Andosol control plots increased from $112 \pm 7 \mathrm{~g}^{\mathrm{kg}} \mathrm{g}^{-1}$ in year 1 to $126 \pm 7$ g. $\mathrm{kg}^{-1}$ in year 13. The control plot $\delta^{13} \mathrm{C}$ remained stable over time (Figure $2 \mathrm{~b}$ ). According to linear regressions, $\delta^{13} \mathrm{C}$ values were about $-23.8 \%$ to $-24.5 \%$ in the three blocks. Block 3 had a slight shift in the initial value for estimated year 0. Including all block, the $\delta^{13} \mathrm{C}$ from year $0(-23.8$ to $-24.1 \%$ ) indicated that the organic matter content was from 
mixed $\mathrm{C}_{3}$ and $\mathrm{C}_{4}$ origins, with a predominance of $\mathrm{C}_{3}$. Vegetation $\delta^{13} \mathrm{C}$ in this Andosol trial was about $-27.8 \%$ (Table 2 ).

\subsection{Organic fertilizer $\delta^{13} \mathrm{C}$}

OF and trials vegetation characteristics are summarized in Table 2. The OF signatures were about $-20.3 \pm 2.8 \%$ for compost and $-24.4 \pm 1.3 \%$ for slurry over the eight study years (years 2 to 9; Table 2; Figure S3). In the Arenosol trial, the $\delta^{13} \mathrm{C}$ difference between the Arenosol (at T0) and applied organic fertilizers $\left(\Delta \delta^{13} \mathrm{C}\right)$ were from $2.9 \pm 0.4 \%$ with compost and $6.9 \pm 0.4$ \%o with slurry. As OFs- $\delta^{13} \mathrm{C}$ was from -24.4 to $-20.3 \%$ and vegetation- $\delta^{13} \mathrm{C}$ of $-13.9 \%$, quantification of OF-C avoided $\mathrm{C}$ from vegetation in equation 7. Differences between $\delta^{13} \mathrm{C}_{\text {soilT0 }}$ and $\mathrm{OFs}-\delta^{13} \mathrm{C}$ for the Arenosol trial were high enough for isotopic OF-C quantification.

In the Andosol trial, the $\delta^{13} \mathrm{C}$ difference between the Andosol (at T0) and applied organic fertilizers $\left(\Delta \delta^{13} \mathrm{C}\right)$ was about $3.8 \pm 0.1 \%$ with compost and $0.2 \pm 0.1 \%$ with slurry. As OFs$\delta^{13} \mathrm{C}$ was from -24.4 to $-20.3 \%$ and vegetation- $\delta^{13} \mathrm{C}$ of $-27.8 \%$, quantification of OF-C avoided $\mathrm{C}$ from vegetation either in equation 7. Differences between $\delta^{13} \mathrm{C}_{\text {soilT0 }}$ and compost$\delta^{13} \mathrm{C}$ in the Arenosol trial were high enough for isotopic OF-C quantification. However, as $\delta^{13} \mathrm{C}$ from $\delta^{13} \mathrm{C}_{\text {soilto }}$ with slurry was close, isotopic quantification of OF-C only failed.

\section{$3.3 \delta^{13} \mathrm{C}$ and carbon content of $\mathrm{OF}$-amended soils}

The temporal change of $\delta^{13} \mathrm{C}$ of the Arenosol (Figure 3a) trial showed that amended soils

248 diverged from controls over time. In year 3 , mean $\Delta \delta^{13} \mathrm{C}$ between controls to compost amended plots was about $1.0 \pm 0.2 \%$ and in slurry amended plots about $1.4 \pm 0.05 \%$. In year 13, mean $\Delta \delta^{13} \mathrm{C}$ reached $2.4 \pm 0.3 \%$ in compost amended plots and $3.3 \pm 0.1 \%$ in slurry 251 amended plots. In the Andosol trial, with regard to $\delta^{13} \mathrm{C}$, only compost amended plots 252 significantly differed from control plots over time (Figure $3 \mathrm{~b}$ ). In year 1 , mean $\Delta \delta^{13} \mathrm{C}$ between 
controls to compost amended plots was about $0.9 \pm 0.1 \%$ (about $0.3 \pm 0.1 \%$ in slurry amended plots). In year 13 , mean $\Delta \delta^{13} \mathrm{C}$ reached $1.8 \pm 0.1 \%$ in compost amended plots $(0.2 \pm 0.0 \%$ in slurry amended plots).

Meanwhile the total carbon content of the Arenosol increased from $12.1 \pm 1.3$ to $38.6 \pm 6.1$ g. $\mathrm{kg}^{-1}$ between years 3 and 13 in the compost amended plots (Figure $4 \mathrm{a}$ ) and from $13.2 \pm 1.4$ to $29.5 \pm 0.1$ g.kg ${ }^{-1}$ in the slurry amended plots (Figure 4b). The total carbon content of the Andosol increased from $111.3 \pm 3.9$ to $152.7 \pm 5.9 \mathrm{~g} . \mathrm{kg}^{-1}$ between years 1 and 13 in the compost amended plots (Figure 4c) and from $107.1 \pm 4.7$ to $136.2 .1 \pm 6.9{\mathrm{~g} \cdot \mathrm{kg}^{-1}}^{-1}$ the slurry amended plots (Figure 4d).

\subsection{Quantification of soil OF-C via the differential, isotopic synchronic and isotopic} asynchronic methods

In Figure 4, to fully understand the significance of the three methods, we represented every quantification method and displayed its significance by t-test student using stars (see method part 2.7).

In the Arenosol with compost inputs, compost-C quantifications increased over time (Figure 4a), i.e. in year 13, $53 \%$ with the differential method, $56 \%$ with the isotopic synchronic method and only $31 \%$ with the asynchronic isotopic method. The p-value were significant only in the final 2 years (years 12 and 13) with the differential method and from year 9 to 13 with the isotopic synchronic method. In the Arenosol with slurry inputs, slurry-C contribution also increased over time (Figure 4b), i.e. in year 13, $39 \%$ with the differential method, $40 \%$ with the isotopic synchronic method and only $28 \%$ with the asynchronic isotopic method. The p-values were more significant in the final years for the three methods and the most significant using the synchronic isotopic method. In the last year, in the Arenosol trial, the synchronic isotopic methods estimated more OF-C than the other methods 
and was more p-values significant. The OF-C estimations were roughly the same for the differential method and lower for the asynchronic method.

In the Andosol with compost inputs, compost-C contribution also increased over time (Figure 4c), i.e. in year 13, $17 \%$ with the differential method, $43 \%$ with the isotopic synchronic method and $36 \%$ with the asynchronic isotopic method. The differential method revealed lower OF-C proportions over the years. All methods were p-value significant from year 7 to year 13, the last year all methods had the same significance. In the Andosol with slurry inputs, as it was not possible to use the isotopic methods, OF-C was only estimated by the differential method (Figure 4d). Slurry-C did not significantly increase over time. In year 13 , the estimation reached $8 \%$ and the p-values were not significant.

Using the synchronic method and only significant quantifications years (Figure 4; p-values $<0.05$ ), the OF-C stock estimations were plotted against total OF inputs (Figure 5). OF-C content in the Arenosol was higher in compost amended plots than in slurry amended plots ( $23 \%$ and $8 \%$, respectively). The final carbon stock in $0-15 \mathrm{~cm}$ (meaning retention percentage from linear regressions of Figure 5) in the compost amended Arenosol was about 27,094 $\mathrm{kgC}_{\mathrm{ha}} \mathrm{h}^{-1}$ and 20,552 $\mathrm{kgC}^{-\mathrm{ha}^{-1}}$ with slurry inputs. Compost-C content in the Andosol was higher than in the Arenosol (36\% and $23 \%$, respectively). Andosol and Arenosol only differed with respect to the soil type and climatic conditions; the same compost was spread over this 13-year experiment. The final compost-C stock in the Arenosol reached 27,094 $\mathrm{kgC} \cdot \mathrm{ha}^{-1}$ and 42,408 $\mathrm{kgC} \cdot \mathrm{ha}^{-1}$ in the Andosol.

\section{Discussion}

\subsection{Relevance of the 3 methods for quantifying OF contribution to SOM}

\subsubsection{Isotopic methods focuses on the direct effect of OFs on the SOM}

The synchronic isotopic method estimated more OF-C than the differential method in the 
Arenosol and Andosol trials (Figure 4). Lynch et al [38] also found that the synchronic

302 isotopic method estimated higher proportion of OF-C than the differential method among three fertilization treatments (i.e. corn sillage compost, dairy manure compost and sewage sludge compost). This difference in OF-C proportion could be explained by two nonexclusive factors:

(i) The repeated OF applications that may have modified the vegetation and its $\mathrm{C}$ inputs. It has been reported that $\mathrm{OF}$ can alter the plant community composition [43], [44] leading to different $C$ inputs relative to control plots [45], [46]. In the Andosol trial, modification of the vegetation composition was revealed by the replacement of Dactylis ( $\mathrm{C}_{3}$ plant-group) in the mineral-fertilized control plots, and of Bromus (C3 plant-group) in the plot with OF amendment (Tillard, pers. comm.). Lower belowground biomass production in the OF plots would likely result in underestimation of the direct OF contribution to SOM with the differential method (as measured in the Andosol, Figure 4c). In the Arenosol trial, the vegetation composition did not change during the experiment (Tillard, pers. comm.).

(ii) Mineralization of the initial soil organic $\mathrm{C}$ (Figure 1) could be higher in the OFamended plots, e.g. through a priming effect [22], [23]. The priming effect involves significant changes in soil organic matter renewal [22], possibly caused by OF input. The latter could accelerate mineralization of the initial $\mathrm{C}$ and thus gradually replace part of this fraction. In such cases, the direct contribution of the OF would be underestimated by the differential method. Organic fertilization is a common practice leading to considerable input of relatively labile $\mathrm{C}$ into agricultural soils. However, studies dealing with OF-induced SOM priming-effect remain very scarce most likely due to the methodological challenge of labeling OF with ${ }^{13} \mathrm{C}$.

To conclude, the differential method based on total carbon did not allow quantification of 
OF-C regardless of vegetation changes or mineralization of initial soil organic $\mathrm{C}$. The isotopic method, on the other hand, measures the proportion of each element by the isotopic signature. It can directly measure the fate of $\mathrm{C}$ contributed by OFs without artefacts related to indirect effects. Where the differential approach measures the overall effect of the organic fertilization practice, the isotopic approach measures the fate of $\mathrm{C}$ from the OF in the soil and ignores the indirect effects of the practice (e.g. changes of vegetation or priming).

\subsubsection{Synchronic isotopic method take into consideration SOM evolution in the control}

The synchronic isotopic method estimated significantly more OF-C than the asynchronic isotopic method in the Arenosol trial (Figure 4a-b). Differences were smaller in the Andosol trial (Figure 4c). The distinction between the asynchronic and synchronic method was the control value used in the mixing model (equations 7 and 8). By the asynchronic method, it was considered that the $\delta^{13} \mathrm{C}$ signature of the control soil over time was equal to the $\delta^{13} \mathrm{C}$ of the amended plot before OF application. By the synchronic method, the $\delta^{13} \mathrm{C}$ of the amended and control soils were measured on the same sampling date, on two adjacent plots. Variations in the control $\delta^{13} \mathrm{C}$ could thus be subtracted when implementing this method. A change in the $\delta^{13} \mathrm{C}$ pattern in the control soils over time was observed (Figure 2) and attributed to $\mathrm{C}$ input from vegetation (SOM from vegetation in Figure 1) during the experiment. The impact of the vegetation on control soil $\delta^{13} \mathrm{C}$ variation pattern was larger in the Arenosol than in the Andosol (Figure 3). The asynchronic method cannot integrate vegetation changes during the time of the experiment, which probably explain the high differences of $\mathrm{C}$ quantification observed between asynchronic and synchronic methods for the Arenosol. Due to the temporal changes in the controls, the synchronic method appeared therefore as the most accurate isotopic method when control plots are available. The asynchronic method is nevertheless more cost-effective because there are fewer samples to analyse than with the synchronic 
method. The experiment is also simpler to implement because it does not require a control plot but just requires the soil signature prior to OF spreading. However, the asynchronic method can be used with confidence only if the soil is at isotopic equilibrium (control plot $\delta^{13} \mathrm{C}$ constant over the course of the experiment).

In our case, the synchronic isotopic method was better for determining the OF field potential to supply SOM. The differential method could be used to estimate the overall effect of organic fertilization, integrating both direct and indirect effects of OF applications. The differential method remains the simplest to carry out, whereas the isotopic method can only be applied with an appropriate $\delta^{13} \mathrm{C}$ system $\left(\mathrm{OF}-\delta^{13} \mathrm{C}\right.$ differentiated from other $\delta^{13} \mathrm{C}$ sources $)$. Yet sometimes in case of minor OF-C inputs, the total carbon content is not enough to differentiate amended plots from controls [29].

\subsection{Resolution and sensitivity of the OF isotopic method}

The synchronic isotopic method was found to be the most suitable in our study, but certain precautions should be taken regarding its use. As stated by the pioneers of the ${ }^{13} \mathrm{C}$ natural abundance method, it is necessary to ensure that the limit of resolution is exceeded and to assess the risk of bias due to error propagation [4], [8].

The limit of resolution is reached when the effects of OF application on SOM is sufficiently strong that a significant difference in the considered parameter can be established between two samples. This requirement applies equally to the isotopic method (parameter is $\delta^{13} \mathrm{C}$ ) and to the differential method (parameter is TOC). For the isotopic method, it is therefore necessary to ensure that the $\delta^{13} \mathrm{C}_{\mathrm{OF}}$ is significantly different from the $\delta^{13} \mathrm{C}_{\mathrm{CTRL}}$. importantly, the $\delta^{13} \mathrm{C}_{\mathrm{OFsoil}}$ and $\delta^{13} \mathrm{C}_{\mathrm{CTR} \text { soil }}$ should be significantly different to compute from the mixing model the proportion of OF-derived soil-C at a given date. The first condition ( $t-$ test between $\delta^{13} \mathrm{C}_{\mathrm{OF}}$ and $\delta^{13} \mathrm{C}_{\mathrm{CTRL} \text { soil }}$ ) was acquired for all sampled years. The second condition 
375 (t-test between $\delta^{13} \mathrm{C}_{\mathrm{OFsoil}}$ and $\delta^{13} \mathrm{C}_{\mathrm{CTRLsoil}}$ ) was not acquired for some years at the beginning of 376 the experiment, which is why the final OF-C retention by isotopes was not calculated on these 377 years (Figure 5). According to the isotopic mixing equations (equations 7 and 8), the quantification accuracy is higher when the OF signature differs from that of the soil. The standard deviation of OF-C quantification between the three plots decreased as the $\Delta \delta^{13} \mathrm{C}$ increases. The $\mathrm{OF}$ must have a high soil $\Delta \delta^{13} \mathrm{C}$ and a stable temporal signature in time to ensure accurate quantification from the beginning of the experiment.

Whatever the number of repetitions performed, attention should be paid to the risk of bias due to the propagation of errors in the mixing equation [8]. The sensitivity analysis (see part 2.8) of the mixing equation according to natural variations in the parameters revealed that the variable with the least impact was $\delta^{13} \mathrm{C}_{\mathrm{CTRL} \text { soil }}$, then $\delta^{13} \mathrm{C}_{\mathrm{OFsoil}}$, whereas $\delta^{13} \mathrm{C}_{\mathrm{OF}}$ was the variable with the greatest impact (Table S2).

Variability in the $\delta^{13} \mathrm{C}_{\mathrm{CTRLsoil}}$, although low, could be attributed to the block variability (Figure 2; block 1 for the Arenosol and block 3 for the Andosol). In the Arenosol trial, the maximum $\delta^{13} \mathrm{C}$ variation between blocks was up to $1.2 \%$ and up to $0.4 \%$ in the Andosol trial. This block variability revealed short-scale variability. The Arenosol trial was conducted in a high school test plot that had been cultivated for a long time. The cropping history may vary over short distances. A solution would be to process blocks independently. Reduce the distance between controls and $\mathrm{OF}$ amended plots could lower the $\delta^{13} \mathrm{C}$ spatial variability. Working on a per-block basis reduced our spatial variability but it would be essential to check a similar signature of the unamended plots prior to the first inputs.

The $\delta^{13} \mathrm{C}_{\mathrm{OFs} s i l}$ variability could also have two explanations. (i) The first concerns the sampling variability inherent to long-term trials (equipment and operator changes). This sampling variability may be reduced by linear regressions that average these values. (ii) And due to high OF incorporations, soil horizon must change over time (swelling) especially for 
andosol which have high OM-stabilization capacities [47], [48]. A 0-15 cm horizon sampled at the start of an experiment might not correspond to the same horizon 13-years later.

$\delta^{13} \mathrm{C}_{\mathrm{OF}}$ was the variable with the greatest impact on the equation. OFs applied to the soils over the 13 years of the experiment were subjected to temporal variations, with standard deviations of about $2.8 \%$ for the compost and $1.3 \%$ for the slurry (Figure S3). Such isotopic variation was previously observed over 6 years by Gerzabek et al. (1997) [34] in fields amended with green manure compost (standard deviation about $1.12 \%$ ), animal manure $(0.77$ $\%$ ) and peat $(0.36 \%)$. The composition of OF parent materials can be a major source of $\delta^{13} \mathrm{C}$ variation. A slight change in the livestock diet can have a marked impact on the $\delta^{13} \mathrm{C}$ of faeces. The $\delta^{13} \mathrm{C}$ of the plant fraction of the $\mathrm{OF}$ can also vary since compounds like lignin can be ${ }^{13} \mathrm{C}$ depleted relative to other plant tissues [49], [50]. Consequently, variations in parent material proportions over time (litter/faeces ratio) was probably a major source of variability for $\mathrm{OF}-\delta^{13} \mathrm{C}$ throughout the study. Another source of variability could be related to $\mathrm{OF}$ transformations that may occur during storage and the composting process, leading to isotopic fractionation. $\mathrm{C}$ biotransformation might increase the $\delta^{13} \mathrm{C}$ ratio of OF during the composting process. Here with yearly quantification for 9 years out of 13 , OF-variations factor was the largest of the 3 factors in the mixing model equation 7. Regular intra- and inter-annual $\delta^{13} \mathrm{C}$ analysis is therefore strongly recommended to ensure the validity of the results obtained with the mixing equation.

\subsection{An isotopic method to study the factor controlling soil OF-C sequestration}

This study case demonstrated that the synchronic isotopic method can be used to investigate factors controlling $\mathrm{OF}-\mathrm{C}$ retention.

Less compost-C was stabilized over time in the Arenosol as compared to the Andosol (23\% and $36 \%$ retention, respectively), underlying the effect of the soil and the climate since the 
same amount of OF were applied at both sites. The impact of the soil type was suggested by

425 Kristiansen et al. (2005), who reported a retention percentage ranging from $11 \%$ to $15 \%$ on four arable soils [35]. In contrast, Thomsen and Christiansen (2010) did not observe any soil type influence [36]. In our study, the Réunion Andosol contains poorly crystalline material [47] while storing large amounts of organic matter that has a low renewal rate [48]. The soil type-dependent retention could be explained by the high retention capacity of the Andosol compared to the Arenosol, but it could also be explained by the cooler climatic conditions that prevailed in the Andosol plot, with higher rainfall than in the Arenosol plot. Cooler climatic conditions can induce slower organic matter decomposition and renewal in soils and thus slower organic matter mineralization. The combined effect of the soil mineralogy and climate affected the long-term stabilization (13 years) of the applied OFs, with higher stabilization in the Andosol trial.

Furthermore, the Arenosol trial showed a retention of $8 \%$ for the slurry but of $23 \%$ for the compost, demonstrating a second impact related to the quality of the OF. A difference in retention related to the OF nature was also observed by Lynch et al. (2006) [38] and Thomsen and Christiensen (2010) [36]. Lynch et al. (2006) [38] observed higher retention for corn sillage compost (89\%), and lower rates for sewage sudge compost (63\%) and dairy manure compost (42\%). Thomsen and Christensen (2010) observed higher retention for sheep faeces (30\%) than for aboveground fresh maize biomass (19\%)[36]. In our case, compost-derived carbon has a composting step where a large part of the labile carbon may have been removed. Slurry did not have this composting stage, thus explaining why a large part of applied slurryderived $\mathrm{C}$ might be directly mineralized. Moreover, as the slurry applications are massive, there may be a toxic impact on microorganisms that could slow down OF decomposition. In our case, the extent of $\mathrm{C}$ retention differed by threefold when comparing the two OFs. The nature of the applied organic materials was therefore a major factor in the long-term (13 
years) stabilization of carbon.

By focusing directly on the fate of OF-C in the soil, the synchronic isotopic method thus may provide an opportunity to study the mechanisms of sequestration in the soil of $\mathrm{C}$ applied with organic fertilizers.

\section{Conclusion}

We compared three methods for quantifying carbon from organic fertilizers (OF-C) in an Arenosol and an Andosol trial under tropical climatic conditions, i.e. the differential method, the synchronic isotopic method and the asynchronic isotopic method. The differential method was the simplest to use since it did not require a specific $\delta^{13} \mathrm{C}$ system for OF-C calculation. However, the indirect effects (changes in vegetation and mineralization link to OFs input) cannot be subtracted from it. This effect had a major influence on the final compost-C quantifications in the Andosol trial, with $17 \pm 8 \%$ found using the differential method compared to $43 \pm 3 \%$ with the synchronic isotopic method. The asynchronous method would be very useful when there are no control plots, but the control system without OF input must be isotopically stable through time, unlike the Arenosol control system here. Here, $\delta^{13} \mathrm{C}$ variations of controls plots were detected from the crop-C over time. The isotopic synchronic method was therefore the most appropriate for subtracting crop-C from the OF-C. Yet there are other methodological variabilities to consider, such as, spatial $\delta^{13} \mathrm{C}$ variations, sampling variability in long-term studies and mostly $\mathrm{OF}-\delta^{13} \mathrm{C}$ variations over time. The application of the synchronous isotopic method revealed potentialities to quantify the OF-C retention factors (e.g. soil type influence, OF nature as well as climate type). In our case study the compost-C retention rate in the Andosol was up to $36 \%$ whereas compost-C in the Arenosol reached only $23 \%$, revealing the marked influence of climate and soil type. The slurry-C retention rate in the Arenosol was only about $8 \%$ compared to compost-C (up to $23 \%$ ), revealing a OF nature 
influence, thus highlighting the importance of the $\mathrm{OF}$ nature on long-term $\mathrm{C}$ stabilization.

\section{Acknowledgements}

We thank Mathias Christina, Marion Collinet, Matthieu Bravin and Adrien Duvivier for their assistance provided throughout this study. The authors thank Expédit Rivière, Sicalait and the Lycée Agricole of Saint-Joseph for financing, maintenance and sampling of trials. We thank the Conseil regional de La Réunion, the French Ministry of Agriculture and Food, the European Union (FEDER program, grant $n^{\circ}$ GURTDI 20151501-0000735), CIRAD for funding A. Versini (CIRAD) within the framework of the Services et impacts des activités agricoles en milieu tropical project (SIAAM) and the ANR NanoSoilC - 16-CE01-0012-01 Project.

This paper is dedicated to Jerome Balesdent, Research Director at INRAE who died prematurely at the age of 62. Jérôme was a senior scientist at INRAE and one of the most renowned French soil scientists of his generation. Jérôme was a recognized pioneer in the use of stable $\mathrm{C}$ isotopes for studying SOM dynamics in C3/C4 transitions. Here we would like to pay tribute to the great soil scientist and generous man he was. He will be greatly missed by the soil science community.

Data are available upon request to the corresponding author.

\section{Disclosure statement}

No potential conflict of interest was reported by the author(s).

\section{References}

1. Soussana JF et al. Matching policy and science: Rationale for the ' 4 per 1000 - soils for food security and climate' initiative. Soil and Tillage Research 188, 3-15 (2019).

2. Trumbore SE. Comparison of carbon dynamics in tropical and temperate soils using radiocarbon measurements. Global Biogeochemical Cycles 7, 275-290 (1993).

3. Mathieu JA, Hatté C, Balesdent J et al. Deep soil carbon dynamics are driven more by soil type than by climate: a worldwide meta- analysis of radiocarbon profiles. Global Change Biology 21, 4278-4292 (2015).

4. Balesdent J, Mariotti A and Guillet B. Natural 13C abundance as a tracer for studies of soil organic matter dynamics. Soil Biology and Biochemistry 19, 25-30 (1987).

5. Glaser B. Compound-specific stable-isotope $(\delta 13 \mathrm{C})$ analysis in soil science. Journal of Plant Nutrition and Soil Science 168, 633-648 (2005).

6. Boutton TW, Archer SR, Midwood AJ et al. $\delta 13 \mathrm{C}$ values of soil organic carbon and their use in documenting vegetation change in a subtropical savanna ecosystem. Geoderma 82, 5-41 (1998). 
7. O’Leary MH. Carbon Isotopes in Photosynthesis. BioScience 38, 328-336 (1988).

507 8. Balesdent J and Mariotti A. Measurement of Soil Organic Matter Turnover Using 13C Natural

508 Abundance. in Mass spectrometry of soils 83-111 (1996).

509 9. Farquhar GD, Ehleringer JR and Hubick KT. Carbon Isotope Discrimination and 510 Photosynthesis. Annual Review of Plant Physiology and Plant Molecular Biology 40, 503-537 (1989).

511 10. Gebauer G, Schulumacher MI, Krstić B et al. Biomass production and nitrate metabolism of 512 Atriplex hortensis L. (C3 plant) and Amaranthus retroflexus L. (C4 plant) in cultures at different levels 513 of nitrogen supply. Oecologia 72, 303-314 (1987).

514 11. Gebauer G, Preiss K and Gebauer AC. Partial mycoheterotrophy is more widespread among 515 orchids than previously assumed. New Phytologist 211, 11-15 (2016).

516 12. Giesemann $\mathrm{P}$ et al. Dark septate endophytes and arbuscular mycorrhizal fungi (Parismorphotype) affect the stable isotope composition of 'classically' non-mycorrhizal plants. Functional Ecology 34, 2453-2466 (2020).

13. Giesemann P, Rasmussen HN, Liebel HT et al. Discreet heterotrophs: green plants that receive fungal carbon through Paris-type arbuscular mycorrhiza. New Phytologist 226, 960-966 (2020).

14. Balesdent $\mathbf{J}$ et al. Atmosphere-soil carbon transfer as a function of soil depth. Nature 559, 599-602 (2018).

15. Jastrow JD, Miller RM and Boutton TW. Carbon Dynamics of Aggregate-Associated Organic Matter Estimated by Carbon-13 Natural Abundance. Soil Science Society of America Journal 60, 801526807 (1996).

16. Liao JD, Boutton TW and Jastrow JD. Organic matter turnover in soil physical fractions following woody plant invasion of grassland: Evidence from natural $13 \mathrm{C}$ and $15 \mathrm{~N}$. Soil Biology and Biochemistry 38, 3197-3210 (2006).

530 17. Bol R, Poirier N, Balesdent $\mathrm{J}$ et al. Molecular turnover time of soil organic matter in particlesize fractions of an arable soil. Rapid Communications in Mass Spectrometry 23, 2551-2558 (2009).

532 18. Lou $\mathrm{Y}$, Wang $\mathrm{J}$ and Liang $\mathrm{W}$. Impacts of 22-year organic and inorganic $\mathrm{N}$ managements on soil organic $\mathrm{C}$ fractions in a maize field, northeast China. CATENA 87, 386-390 (2011).

19. Paetsch L, Mueller CW, Rumpel C et al. Urban waste composts enhance OC and N stocks after long-term amendment but do not alter organic matter composition. Agriculture, Ecosystems \& Environment 223, 211-222 (2016).

20. Liu $\mathrm{H}$ et al. 16-Year fertilization changes the dynamics of soil oxidizable organic carbon fractions and the stability of soil organic carbon in soybean-corn agroecosystem. Agriculture, Ecosystems \& Environment 265, 320-330 (2018).

540 21. Liang F et al. Two-decade long fertilization induced changes in subsurface soil organic carbon stock vary with indigenous site characteristics. Geoderma 337, 853-862 (2019).

542 22. Kuzyakov Y, Friedel JK and Stahr K. Review of mechanisms and quantification of priming effects. Soil Biology and Biochemistry 32, 1485-1498 (2000).

544 23. Fontaine S, Mariotti A and Abbadie L. The priming effect of organic matter: a question of microbial competition? Soil Biology and Biochemistry 35, 837-843 (2003). 

Aggregates. Soil Science Society of America Journal 60, 1547-1551 (1996).

25. Balesdent $\mathrm{J}$. Les isotopes du carbone et la dynamique des matières organiques des sols. Cahiers Agricultures 7, 201-206 (1) (1998).

26. Dignac MF et al. Carbon-13 natural abundance as a tool to study the dynamics of lignin monomers in soil: an appraisal at the Closeaux experimental field (France). Geoderma 128, 3-17 (2005).

27. Rasse DP et al. Lignin turnover in an agricultural field: from plant residues to soil-protected fractions. European Journal of Soil Science 57, 530-538 (2006).

28. Amelung W, Bol R and Friedrich C. Natural 13C abundance: a tool to trace the incorporation of dung-derived carbon into soil particle-size fractions. Rapid Communications in Mass Spectrometry 13, 1291-1294 (1999).

29. Bol R, Amelung W, Friedrich $\mathrm{C}$ et al. Tracing dung-derived carbon in temperate grassland using 13C natural abundance measurements. Soil Biology and Biochemistry 32, 1337-1343 (2000).

30. Glaser B et al. Short-term sequestration of slurry-derived carbon and nitrogen in temperate grassland soil as assessed by $13 \mathrm{C}$ and $15 \mathrm{~N}$ natural abundance measurements. Journal of Plant Nutrition and Soil Science 164, 467-474 (2001).

31. Carpenter-Boggs LA, Carlson BR, Higgins SS et al. Decomposition of Dairy Manure Assessed in the Field by Monitoring Natural Abundance of 13 C. Soil Science Society of America Journal 78, 1949-1952 (2014).

32. Rochette P, Angers DA and Côté D. Soil Carbon and Nitrogen Dynamics Following Application of Pig Slurry for the 19th Consecutive Year I. Carbon Dioxide Fluxes and Microbial Biomass Carbon. Soil Science Society of America Journal 64, 1389-1395 (2000).

33. Angers DA, Rochette P, Chantigny MH et al. Use of $13 \mathrm{C}$ abundance to study short-term pig slurry decomposition in the field. Soil Biology and Biochemistry 39, 1234-1237 (2007).

34. Gerzabek MH, Pichlmayer F, Kirchmann $\mathrm{H}$ et al. The response of soil organic matter to manure amendments in a long-term experiment at Ultuna, Sweden. European Journal of Soil Science 48, 273-282 (1997).

35. Kristiansen SM, Hansen EM, Jensen LS et al. Natural 13C abundance and carbon storage in Danish soils under continuous silage maize. European Journal of Agronomy 22, 107-117 (2005).

36. Thomsen IK and Christensen BT. Carbon sequestration in soils with annual inputs of maize biomass and maize-derived animal manure: Evidence from 13C abundance. Soil Biology and Biochemistry 42, 1643-1646 (2010).

37. Nicoloso RS, Rice CW, Amado TJC et al. Carbon saturation and translocation in a no-till soil under organic amendments. Agriculture, Ecosystems \& Environment 264, 73-84 (2018).

38. Lynch DH, Voroney RP and Warman PR. Use of $13 \mathrm{C}$ and $15 \mathrm{~N}$ natural abundance techniques Biology and Biochemistry 38, 103-114 (2006).

39. Gerzabek MH, Haberhauer G and Kirchmann H. Soil Organic Matter Pools and Carbon-13 Natural Abundances in Particle-Size Fractions of a Long-Term Agricultural Field Experiment Receiving Organic Amendments. Soil Science Society of America Journal 65, 352-358 (2001). 
40. USS Working Group WRB. World Reference Base for Soil Resources 2014, update 588 2015.International soil classification system for naming soils and creating legends for soil maps. 589 World Soil Resources Reports (2015).

590 41. Coplen TB et al. After two decades a second anchor for the VPDB $\delta 13 \mathrm{C}$ scale. Rapid 591 Communications in Mass Spectrometry 20, 3165-3166 (2006).

592 42. Alexander EB. Bulk Densities of California Soils in Relation to Other Soil Properties 1. Soil 593 Science Society of America Journal 44, 689-692 (1980).

594 43. Liu W, Zhu YG, Christie P et al. Botanical composition, production and nutrient status of an 595 originally Lolium perenne-dominant cut grass sward receiving long-term manure applications. Plant 596 Soil 326, 355 (2009).

597 44. Blumenthal DM, LeCain DR and Augustine DJ. Composted manure application promotes 598 long-term invasion of semi-arid rangeland by Bromus tectorum. Ecosphere 8, e01960 (2017).

599 45. De Deyn GB, Cornelissen JHC and Bardgett RD. Plant functional traits and soil carbon 600 sequestration in contrasting biomes. Ecol. Lett. 11, 516-531 (2008).

601 46. Steinbeiss $\mathrm{S}$ et al. Plant diversity positively affects short-term soil carbon storage in 602 experimental grasslands. Global Change Biology 14, 2937-2949 (2018).

603 47. Levard C et al. Structure and distribution of allophanes, imogolite and proto-imogolite in 604 volcanic soils. Geoderma 183-184, 100-108 (2012).

605 48. Basile-Doelsch I, Balesdent J and Rose J. Are Interactions between Organic Compounds and 606 Nanoscale Weathering Minerals the Key Drivers of Carbon Storage in Soils? Environ. Sci. Technol. 607 49, 3997-3998 (2015).

608 49. Benner R, Fogel ML, Sprague EK et al. Depletion of $13 \mathrm{C}$ in lignin and its implications for 609 stable carbon isotope studies. Nature 329, 708-710 (1987).

610 50. Cayet $\mathrm{C}$ and Lichtfouse E. $\delta 13 \mathrm{C}$ of plant-derived n-alkanes in soil particle-size fractions. 611 Organic Geochemistry 32, 253-258 (2001). 
Table 1. Summary of similar OF-C estimation experiments using $13 \mathrm{C}$ isotopes from the literature. ${ }^{*} \mathrm{C}$ proportion estimation using $\mathrm{C} 3$ of $-27 \%$ and $\mathrm{C} 4$ of $-13 \%$ and not the soil at the beginning of the experiment or without OF. **Estimation by linear regression (see Figure 1).

Table 2. Quality and amount of carbon inputs from the two organic fertilizers applied and vegetation $\mathbf{C}$ data. The two organic fertilizers are averages of 8 samples from years 2 to 9 . Vegetation is a single measurement.

\section{Figure list}

622

623

Figure 1. Schematic representation of carbon origins in experiments with organic inputs. Initial SOM reflects the $\mathrm{C}$ pool before the start of the experiment. SOM from OF are displayed in yellow, SOM from vegetation in green and initial SOM in brown.

Figure 2. Variations in soil $\delta^{13} \mathrm{C}$ in control plots with mineral fertilization of: a) the Arenosol and b) the Andosol. $\delta^{13} \mathrm{C}$ is reported for topsoils $(0-15 \mathrm{~cm})$ in three experimental blocks (block 1: black triangles; block 2: open circles; block 3: black diamonds). Lines correspond to the linear regression of $\delta^{13} \mathrm{C}$ in each block, with a common slope for a given soil type.

Figure 3. Variations in soil $\delta^{13} \mathrm{C}$ in plots amended with organic fertilizers implied on: a) the Arenosol and b) the Andosol. Topsoils $(0-15 \mathrm{~cm})$ receiving compost (squares) and slurry (diamonds) are compared to the control mean (triangles). Each point is the average of three blocks and error bars are \pm one standard deviation of 3 plots (one per block; only two blocks in year 3 in the Arenosol and year 10 in the Andosol). $\boldsymbol{\delta}^{13} \mathbf{C}$ of OFs is displayed as a continuous line over time (green and yellow), the error bar is the standard deviation of values $(\mathrm{n}=8) .(*),(* *)$, And $(* * *)$, indicates $\mathrm{p}$-value significant differences between controls and amended, $\mathrm{P}<0.05,<0.01$ or $<0.001$, respectively

Figure 4. $\mathrm{C}$ content and origin of carbon in the Arenosol and Andosol topsoils (0-15 cm) according to the quantification method. The origin was inferred from the differential method (orange), synchronic isotopic method (red) and asynchronic isotopic method (blue). The dotted error bars are the standard deviation of three total $\mathrm{C}$ quantifications (only two blocks in year 3 for the Arenosol and year 10 for the Andosol). The solid line error bars are standard deviations of three OF-C quantifications. Negative OF-C values using the differential method were set at $\left.0 .{ }^{*}\right),(* *)$, And $(* * *)$, indicates the resolution limit of the methods by student $\mathrm{t}$-test evaluation $(\mathrm{P}<0.05,<0.01$ or $<0.001$, respectively; see method par 2.7)

Figure 5. Carbon stock derived from organic fertilizers as a function of cumulated $\mathrm{C}$ inputs from organic fertilizer amendments $(0-15 \mathrm{~cm}$ soil layer) using the synchronic isotopic method. Linear model of the Andosol compost amended plots with retention of $36 \%\left(\mathrm{R}^{2}=0.93\right), 23 \%$ $\left(\mathrm{R}^{2}=0.94\right)$ in the Arenosol and $8 \%\left(\mathrm{R}^{2}=0.98\right)$ in the Arenosol slurry amended plot. Each point represents the average of the three plots and the error bars are the standard deviation (only two blocks in year 3 for the Arenosol and year 10 for the Andosol). The insert compares data from previous studies with the regression lines of the different modalities. Note that data from literature had a sampling horizon thickness ranging from 4 to $20 \mathrm{~cm}$. 


\begin{tabular}{|c|c|c|c|c|c|c|c|c|c|c|c|c|c|c|}
\hline \multirow{3}{*}{$\begin{array}{l}\text { Sampling } \\
\text { frequency }\end{array}$} & \multirow{3}{*}{ Publication } & \multirow{3}{*}{ Location } & \multirow{3}{*}{ Soil type } & \multirow{3}{*}{$\begin{array}{c}\begin{array}{c}\text { Sampled } \\
\text { depth }\end{array} \\
{[\mathrm{cm}]}\end{array}$} & \multirow{3}{*}{ Type of OF applied } & \multirow{3}{*}{$\begin{array}{c}\text { Time of } \\
\text { experiment }\end{array}$} & \multirow{3}{*}{$\begin{array}{l}\text { Number of } \\
\text { OF } \\
\text { applications } \\
\text { through } \\
\text { time }\end{array}$} & \multicolumn{3}{|c|}{$\delta^{13} \mathrm{C}$ of sources } & \multirow{2}{*}{$\begin{array}{c}\text { OF-C in } \\
\text { the soil at } \\
\text { the end of } \\
\text { the } \\
\text { experiment }\end{array}$} & \multirow[b]{2}{*}{$\begin{array}{c}\text { Total } \\
\text { OF-C } \\
\text { spread }\end{array}$} & \multirow[b]{2}{*}{$\begin{array}{c}\text { Retention } \\
\text { of OF-C }\end{array}$} & \multirow[b]{2}{*}{$\begin{array}{l}\text { Total } \\
\text { OF-C in } \\
\text { soil }\end{array}$} \\
\hline & & & & & & & & OF & Vegetation & $\begin{array}{c}\text { Soil at the } \\
\text { begining of the } \\
\text { experiment or } \\
\text { without OF } \\
\end{array}$ & & & & \\
\hline & & & & & & & & [\%o VPDB] & {$[\%$ VPDB] } & [\% VPDB] & {$[\%]$} & $\begin{array}{c}{\left[\mathrm{kgC} . \mathrm{ha}^{-}\right.} \\
\left.{ }_{1}\right]\end{array}$ & {$[\%]$} & $\left.\begin{array}{c}{[\mathrm{kgClha}} \\
\left.{ }_{1}\right]\end{array}\right]$ \\
\hline \multirow{16}{*}{ Single } & \multirow{2}{*}{$\begin{array}{c}\text { Amelung et } \\
\text { al., } 1999 \\
{[28]}\end{array}$} & \multirow{2}{*}{$\begin{array}{l}\text { North Wyke, } \\
\text { Devon, } \\
\text { southwest of } \\
\text { England }\end{array}$} & \multirow{2}{*}{$\begin{array}{c}\text { Gleyic } \\
\text { cambisol }\end{array}$} & \multirow{2}{*}{$1-5$} & C3 dung & \multirow{2}{*}{70 days } & \multirow{2}{*}{ Single } & -25.6 & -27.4 & - & \multirow{2}{*}{\multicolumn{4}{|c|}{ Results on fractions only }} \\
\hline & & & & & C4 dung & & & -15.4 & -27.4 & - & & & & \\
\hline & \multirow{2}{*}{$\begin{array}{l}\text { Bol et al., } \\
2000[29]\end{array}$} & \multirow{2}{*}{$\begin{array}{l}\text { North Wyke, } \\
\text { Devon, } \\
\text { southwest of } \\
\text { England }\end{array}$} & \multirow{2}{*}{$\begin{array}{c}\text { Gleyic } \\
\text { cambisol }\end{array}$} & \multirow{2}{*}{$1-5$} & C3 dung & \multirow{2}{*}{150 days } & \multirow{2}{*}{ Single } & -25.7 & -27.4 & -27.9 & - & \multirow{2}{*}{14,900} & - & - \\
\hline & & & & & C4 dung & & & -15.4 & -27.4 & -27.9 & 11 & & 12.6 & 1,877 \\
\hline & \multirow{3}{*}{$\begin{array}{c}\text { Gerzabek et } \\
\text { al., 2001 } \\
\text { [39] }\end{array}$} & \multirow{3}{*}{$\begin{array}{l}\text { Uppsala, } \\
\text { Sweden }\end{array}$} & \multirow{3}{*}{$\begin{array}{c}\text { Eutric } \\
\text { Cambisol }\end{array}$} & \multirow{3}{*}{$0-20$} & Green manure & & & -27.3 & $\mathrm{C} 3$ & -26.03 & & & & \\
\hline & & & & & Animal manure & 42 vears & Continuous & -27.5 & $\mathrm{C} 3$ & -26.03 & & Pecults on & etions only & \\
\hline & & & & & \begin{tabular}{|c|} 
Peat \\
Sewage sludge
\end{tabular} & 42 years & Continuous & $\begin{array}{l}-25.6 \\
-25.5\end{array}$ & $\begin{array}{ll}\mathrm{C} 3 \\
\mathrm{C} 3\end{array}$ & $\begin{array}{l}-26.03 \\
-26.03\end{array}$ & & Results on & ctions only & \\
\hline & Glaser $e t$ & North Wyke, & & & C3 dung & & & -30.7 & $\mathrm{C} 3$ & -30 & - & - & - & - \\
\hline & $\begin{array}{c}a l ., \\
2001[30]\end{array}$ & $\begin{array}{l}\text { Devon, } \\
\text { southwest of } \\
\text { England }\end{array}$ & $\begin{array}{l}\text { Dystric } \\
\text { gleysol }\end{array}$ & $0-2$ & C4 dung & 14 days & Single & -21.3 & $\mathrm{C} 3$ & -30 & $<1(0.11)$ & 1,100 & 36 & 396 \\
\hline & & & & & Composting corn sillage & & & -14.0 & $\mathrm{C} 4$ & -28.03 & 33 & 9,200 & 89 & 8,188 \\
\hline & $\begin{array}{l}\text { Lynch } e t \\
\text { al., } 2006\end{array}$ & $\begin{array}{l}\text { Marshwind } \\
\text { Farm, } \\
\text { Masstown, }\end{array}$ & $\begin{array}{c}\text { Orthic } \\
\text { humoferric }\end{array}$ & $0-5$ & Dairy manure compost & 1 year after & Spread over & -26.6 & $\mathrm{C} 4$ & -28.03 & 19 & 10,000 & 42 & 4,200 \\
\hline & [38] & $\begin{array}{l}\text { Truro, Nova } \\
\text { Scotia, }\end{array}$ & podzol & & Sewage sludge compost & & & -25.9 & $\mathrm{C} 4$ & -28.03 & 32 & $\begin{array}{l}10,900 \\
\end{array}$ & 63 & 6,867 \\
\hline & & Canada & & & Liquid dairy manure & & & -27.3 & $\mathrm{C} 4$ & -28.03 & - & 2,900 & - & - \\
\hline & $\begin{array}{c}\text { Carpenter } \\
\text { Boggs et } \\
\text { al., } 2014 \\
{[31]}\end{array}$ & $\begin{array}{l}\text { Washington } \\
\text { university, } \\
\text { Puyallup } \\
\text { Research and } \\
\text { extention } \\
\text { center, USA }\end{array}$ & $\begin{array}{c}\text { Mesic } \\
\text { Fluventic } \\
\text { Haploxerolls }\end{array}$ & $0-15$ & Dairy manure & 120 days & Single & -20.9 & -30.0 & -26.9 & $<0.01$ & 2,722 & - & - \\
\hline & Nicoloso $e t$ & $\begin{array}{l}\text { North farm of } \\
\text { Kansas }\end{array}$ & $\begin{array}{c}\text { Well- } \\
\text { drained }\end{array}$ & $0-5 ; 5-$ & $\begin{array}{l}\text { Chilled tillage, additions } \\
\text { of fresh cattle manure } \\
\text { (from year } 0 \text { to } 12 \text { ) and } \\
\text { composted organic waste } \\
\text { (from year } 13 \text { to } 25 \text { ) } \\
\end{array}$ & & & $\begin{array}{c}-25.9 \text { to }- \\
27.3\end{array}$ & $\begin{array}{c}\mathrm{C} 4 \\
\text { (converted }\end{array}$ & $\begin{array}{l}\text { Year } 2 \text { after OF } \\
\text { spreading :-18.9 }\end{array}$ & - & & $27^{*}$ & $26,300^{*}$ \\
\hline & $\begin{array}{c}\text { al.., } 2018 \\
{[37]}\end{array}$ & $\begin{array}{l}\text { University, } \\
\text { Manattan, } \\
\text { USA }\end{array}$ & $\begin{array}{l}\text { Kennebec } \\
\text { silt loam }\end{array}$ & $\begin{array}{c}15 ; 15- \\
30\end{array}$ & $\begin{array}{l}\text { No tillage, additions of } \\
\text { fresh cattle manure (from } \\
\text { year } 0 \text { to } 12 \text { ) and } \\
\text { composted organic waste } \\
\text { (from year } 13 \text { to } 25 \text { ) }\end{array}$ & 25 years & continous & $\begin{array}{c}\text { (estimated } \\
\text { from } \\
\text { litterature) }\end{array}$ & $\begin{array}{l}\text { in year } 0 \\
\text { from C3 } \\
\text { crop) }\end{array}$ & $\begin{array}{c}\text { to }-19.1(0-5 \\
\text { cm); } 15.8 \text { to }- \\
16.5(15-30 \mathrm{~cm})\end{array}$ & - & 98,800 & $12 *$ & $11,900^{*}$ \\
\hline
\end{tabular}




\begin{tabular}{|c|c|c|c|c|c|c|c|c|c|c|c|c|c|c|}
\hline \multirow{3}{*}{$\begin{array}{l}\text { Sampling } \\
\text { frequency }\end{array}$} & \multirow{3}{*}{ Publication } & \multirow{3}{*}{ Location } & \multirow{3}{*}{ Soil type } & \multirow[b]{2}{*}{$\begin{array}{l}\text { Sampled } \\
\text { depth }\end{array}$} & \multirow[b]{2}{*}{ Type of OF applied } & \multirow[b]{2}{*}{$\begin{array}{c}\text { Time of } \\
\text { experiment }\end{array}$} & \multirow[b]{2}{*}{ 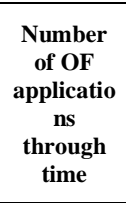 } & \multicolumn{3}{|c|}{$\delta^{13} \mathrm{C}$ of sources } & \multirow[b]{2}{*}{$\begin{array}{l}\text { OF-C in } \\
\text { the soil at } \\
\text { the end of } \\
\text { the } \\
\text { experimen } \\
t\end{array}$} & \multirow[b]{2}{*}{$\begin{array}{l}\text { Total } \\
\text { OF-C } \\
\text { spread }\end{array}$} & \multirow[b]{2}{*}{$\begin{array}{l}\text { Retention } \\
\text { of OF-C }\end{array}$} & \multirow[b]{2}{*}{$\begin{array}{l}\text { Total } \\
\text { OF-C in } \\
\text { soil }\end{array}$} \\
\hline & & & & & & & & OF & Vegetation & $\begin{array}{c}\text { Soil at the } \\
\text { begining of } \\
\text { the } \\
\text { experiment } \\
\text { or without } \\
\text { OF } \\
\end{array}$ & & & & \\
\hline & & & & [cm] & & & & $\begin{array}{c}{[\%} \\
\text { VPDB] } \\
\end{array}$ & [\% VPDB] & [\% VPDB] & [\%] & $\begin{array}{c}{\left[\mathrm{kgC} . \mathrm{ha}^{-}\right.} \\
\left.{ }_{1}\right]\end{array}$ & [\%] & {$\left[\mathrm{kgC} \cdot \mathrm{ha}^{-1}\right]$} \\
\hline \multirow{14}{*}{$\begin{array}{l}\text { Chrono- } \\
\text { sequence }\end{array}$} & \multirow{2}{*}{$\begin{array}{c}\text { Gerzabek et } \\
\text { al., } 1997 \text { [34] }\end{array}$} & \multirow{2}{*}{$\begin{array}{l}\text { Uppsala, } \\
\text { Sweden }\end{array}$} & \multirow{2}{*}{$\begin{array}{l}\text { Eutric } \\
\text { Cambisol }\end{array}$} & \multirow{2}{*}{$0-20$} & Green manure & \multirow[b]{2}{*}{42 years } & \multirow{2}{*}{$\begin{array}{l}\text { Continuou } \\
\mathrm{s}\end{array}$} & -27.3 & $\mathrm{C} 3$ & -26.03 & - & - & - & - \\
\hline & & & & & Animal manure & & & -27.5 & $\mathrm{C} 3$ & -26.03 & 55 & 84,000 & 0 & 30,131 \\
\hline & \multirow{4}{*}{$\begin{array}{l}\text { Kristiansen } e t \\
\text { al., } 2005 \text { [35] }\end{array}$} & $\begin{array}{l}\text { Soil from } \\
\text { Lundgaard in } \\
\text { Askov, } \\
\text { Denmark } \\
\end{array}$ & Sand & \multirow{4}{*}{$0-20$} & \multirow{4}{*}{$\begin{array}{l}\text { Above ground fresh } \\
\text { maize biomass }\end{array}$} & \multirow{4}{*}{14 years } & \multirow{4}{*}{$\begin{array}{l}\text { Continuou } \\
\text { s }\end{array}$} & -25.6 & $\mathrm{C} 4$ & -26.03 & 25 & \multirow{4}{*}{51,100} & 11 & 5,621 \\
\hline & & $\begin{array}{c}\text { Askov, } \\
\text { Denmarck }\end{array}$ & Sandy loam & & & & & -10 & C4 & -27.2 & 18 & & 14 & 7,154 \\
\hline & & $\begin{array}{l}\text { Soil from } \\
\text { Roskilde in } \\
\text { Askov, } \\
\text { Denmark } \\
\end{array}$ & Sandy loam & & & & & -10 & $\mathrm{C} 4$ & -25.4 & 27 & & 14 & 7,154 \\
\hline & & $\begin{array}{l}\text { Soil from } \\
\text { Rønhave in } \\
\text { Askov, } \\
\text { Denmark } \\
\end{array}$ & Sandy loam & & & & & -10 & $\mathrm{C} 4$ & -26.2 & 31 & & 15 & 7,665 \\
\hline & \multirow{4}{*}{$\begin{array}{l}\text { Thomsen and } \\
\text { Christensen, } \\
2010 \text { [36] }\end{array}$} & $\begin{array}{l}\text { Soil from } \\
\text { Lundgaard in }\end{array}$ & \multirow{2}{*}{ Sand } & \multirow{4}{*}{$0-20$} & $\begin{array}{c}\text { Above ground fresh } \\
\text { maize biomass }\end{array}$ & \multirow{4}{*}{9 years } & \multirow{4}{*}{$\begin{array}{c}\text { Continuou } \\
\mathrm{s}\end{array}$} & -12.0 & $\mathrm{C} 4$ & -27.5 & 15 & \multirow{4}{*}{32,000} & 19 & 6,080 \\
\hline & & $\begin{array}{c}\text { Askov, } \\
\text { Denmark } \\
\end{array}$ & & & Sheep faeces & & & -13.7 & $\mathrm{C} 4$ & -27.5 & 22 & & 30 & 9,600 \\
\hline & & \multirow{2}{*}{$\begin{array}{l}\text { Askov, } \\
\text { Denmarck }\end{array}$} & Sandy loam & & $\begin{array}{l}\text { Above ground fresh } \\
\text { maize biomass }\end{array}$ & & & -12.0 & $\mathrm{C} 4$ & -27.5 & 13 & & 19 & 6,080 \\
\hline & & & & & Sheep faeces & & & -13.7 & $\mathrm{C} 4$ & -27.5 & 22 & & 30 & 9,600 \\
\hline & & $\begin{array}{l}\text { Saint-Joseph, } \\
\text { La Réunion }\end{array}$ & & & $\begin{array}{c}\text { Bovine manure } \\
\text { compost }\end{array}$ & & & -20.3 & -14.0 & $\begin{array}{c}-18.2 \text { to } \\
-17^{* *}\end{array}$ & 57 & 117,800 & 23 & 27,094 \\
\hline & & $\begin{array}{c}\text { island, France } \\
\text { (near } \\
\text { Madagascar) }\end{array}$ & Arenosol & & Bovine slurry & & & -24.4 & -14.0 & $\begin{array}{c}-18.2 \text { to } \\
-17^{* * *} \\
\end{array}$ & 41 & 256,900 & 8 & 20,552 \\
\hline & Inis study & $\begin{array}{l}\text { Le plaine des } \\
\text { cafres, } \mathrm{La}\end{array}$ & & $0-12$ & $\begin{array}{c}\text { Bovine manure } \\
\text { compost }\end{array}$ & 13 years & continuous & -20.3 & -27.8 & $\begin{array}{l}-24.3 \text { to } \\
-23.8^{* * *} \\
\end{array}$ & 41 & 117,800 & 36 & 42,408 \\
\hline & & $\begin{array}{l}\text { Réunion island, } \\
\text { France (near } \\
\text { Madagascar) } \\
\end{array}$ & Andosol & & Bovine slurry & & & -24.4 & -27.8 & $\begin{array}{l}-24.3 \text { to } \\
-23.8^{* * *}\end{array}$ & - & 256,900 & - & - \\
\hline
\end{tabular}




\begin{tabular}{|c|c|c|c|c|c|c|}
\hline & $\begin{array}{l}\text { C air- } \\
\text { dried } \\
\text { matter }\end{array}$ & N Kjeldahl & $\begin{array}{l}\text { Dry mass } \\
\left(105^{\circ} \mathrm{C}\right)\end{array}$ & $\delta^{13} \mathrm{C}$ & $\begin{array}{c}\delta^{13} \mathrm{C} \\
\text { temporal } \\
\text { standard } \\
\text { deviation }\end{array}$ & Annual input \\
\hline & {$\left[\mathrm{g} \cdot \mathrm{kg}^{-1}\right]$} & $\begin{array}{l}\text { [g N.kg }{ }^{-1} \text { of dry } \\
\text { mass } 105^{\circ} \mathrm{C} \text { ] }\end{array}$ & [g. $100 \mathrm{~g}^{-1}$ ] & [\%० VPDB] & [\%० VPDB] & {$\left[\mathrm{kg}\right.$ C. ha.$\left.^{-1} \cdot \mathrm{yr}^{-1}\right]$} \\
\hline $\begin{array}{l}\text { Bovine manure } \\
\text { compost }\end{array}$ & 213 & 22 & 46.7 & $(n=8)-20.3$ & 2.8 & 9064 \\
\hline Bovine slurry & 374 & 43 & 9.3 & $(n=8)-24.3$ & 1.3 & 19760 \\
\hline $\begin{array}{c}\mathrm{C}_{4} \text { vegetation in the } \\
\text { Arenosol trial }\end{array}$ & 417 & & & $(n=1)-13.9$ & & \\
\hline $\begin{array}{c}\mathrm{C}_{3} \text { vegetation in the } \\
\text { Andosol trial }\end{array}$ & 414 & & & $(n=1)-27.8$ & & \\
\hline
\end{tabular}

654

655 


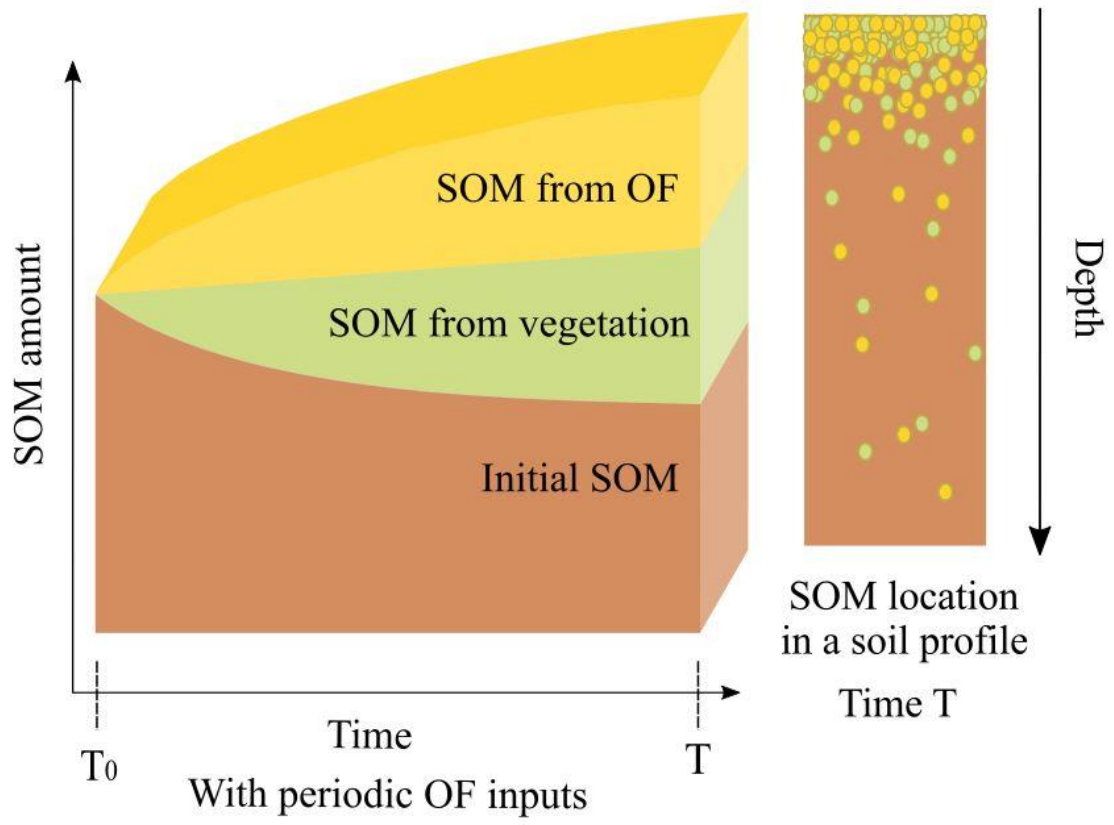


$658 \quad$ Figure 2.
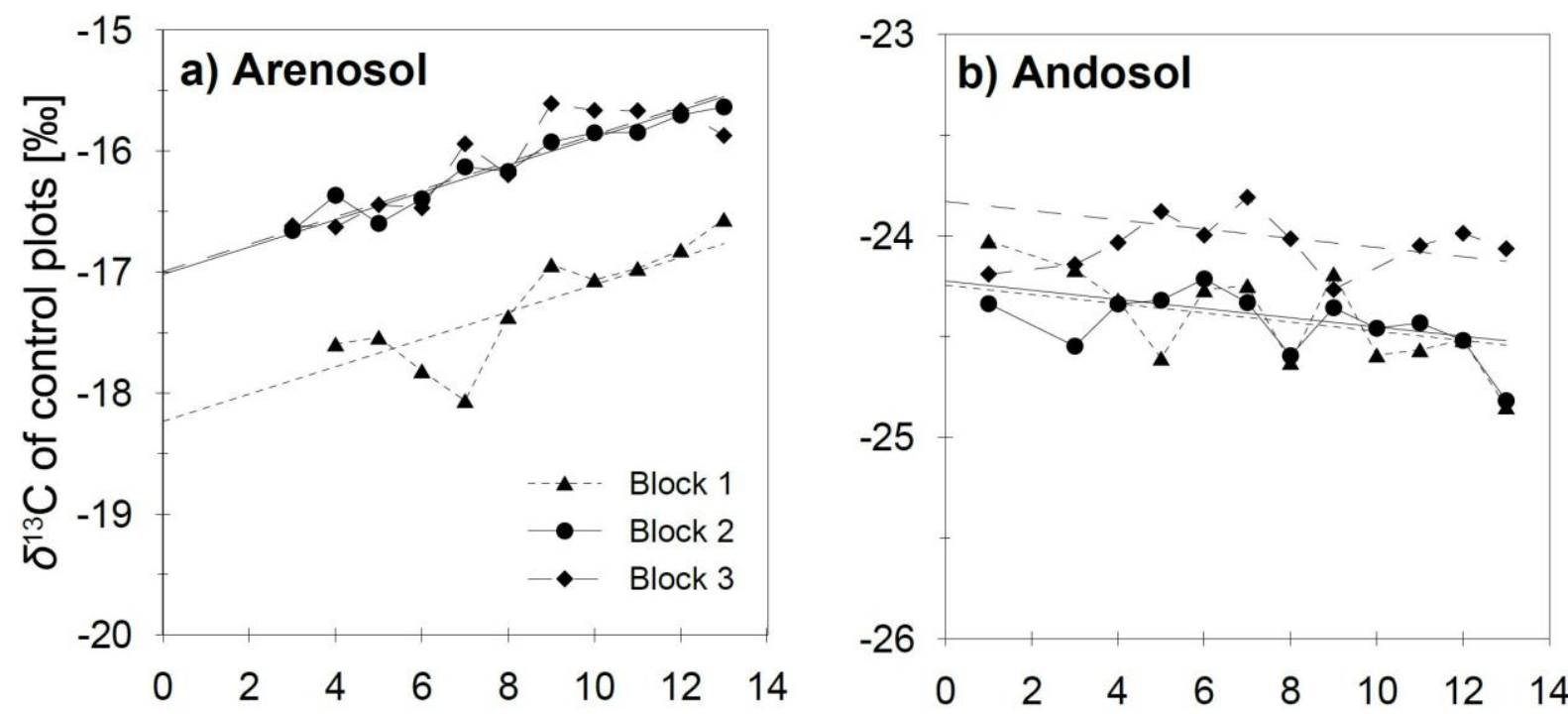

Experimentation duration [yr] 


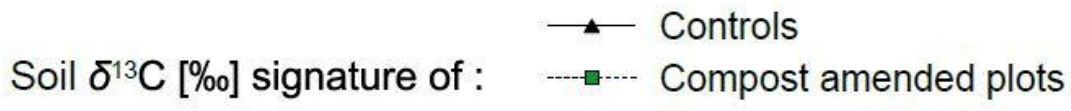 \\ $-\diamond$. Slurry amended plots}

\section{a) Arenosol}

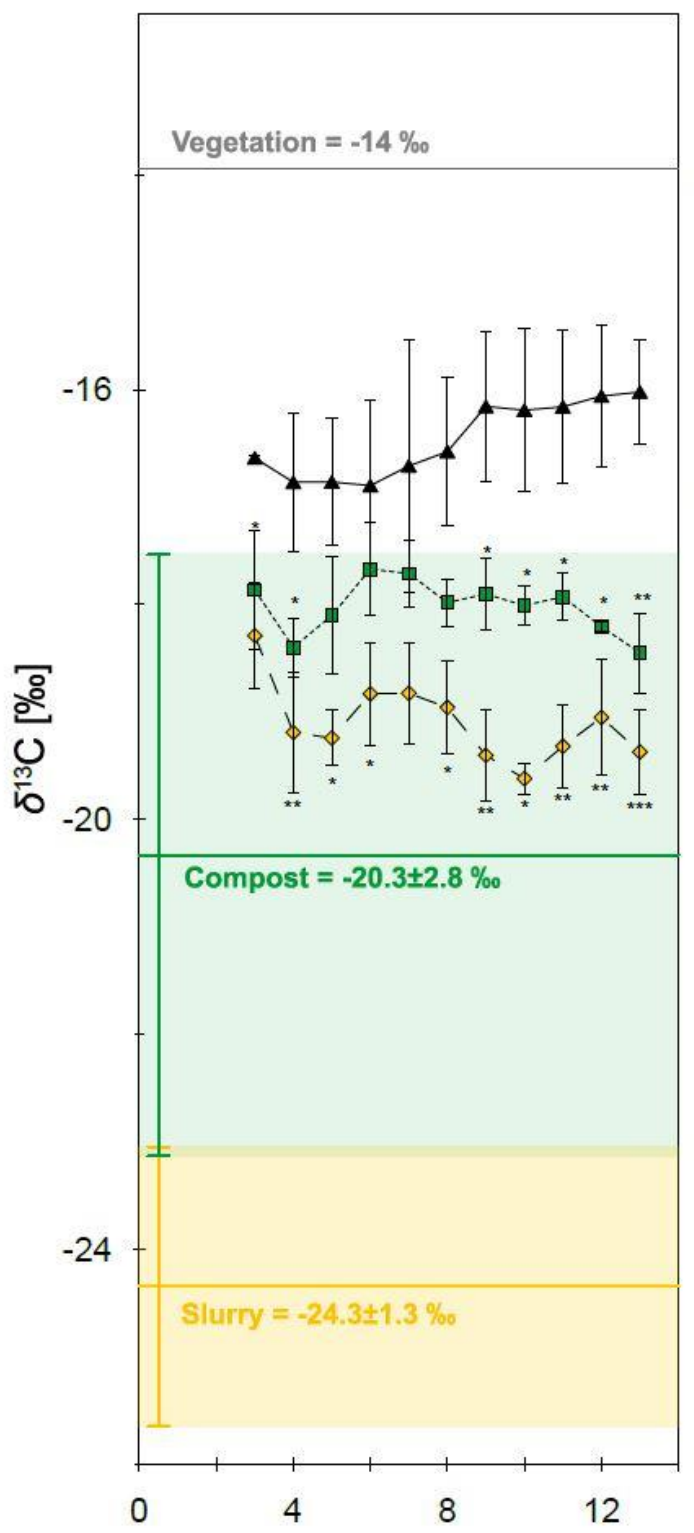

b) Andosol

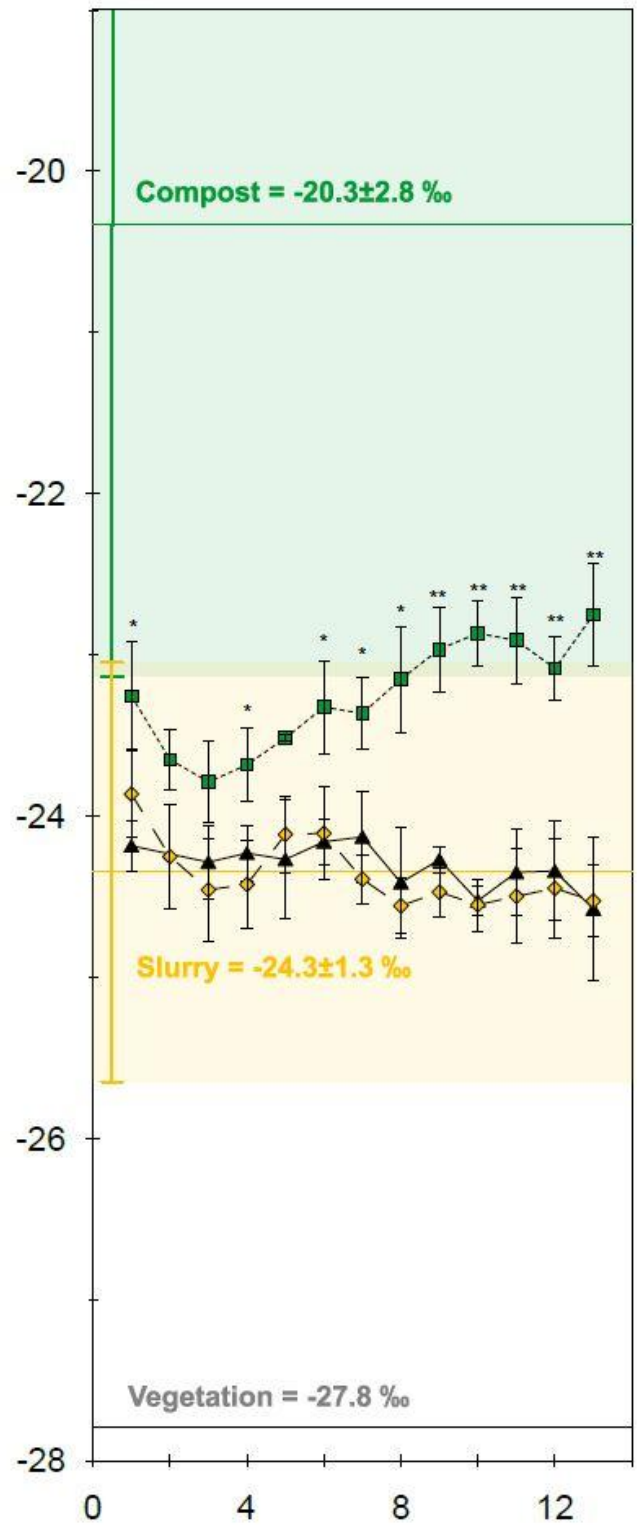

Experimentation duration [yr] 


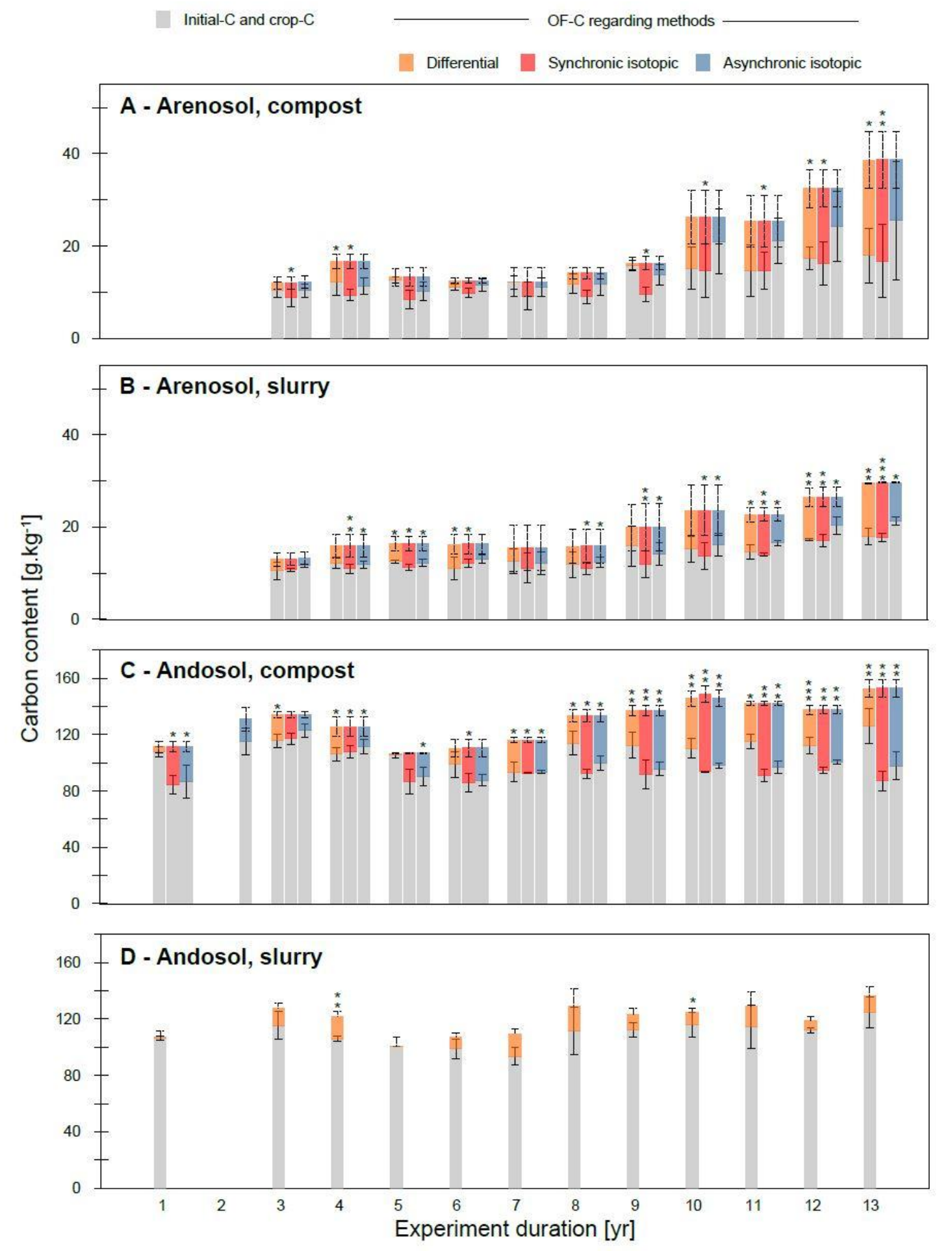



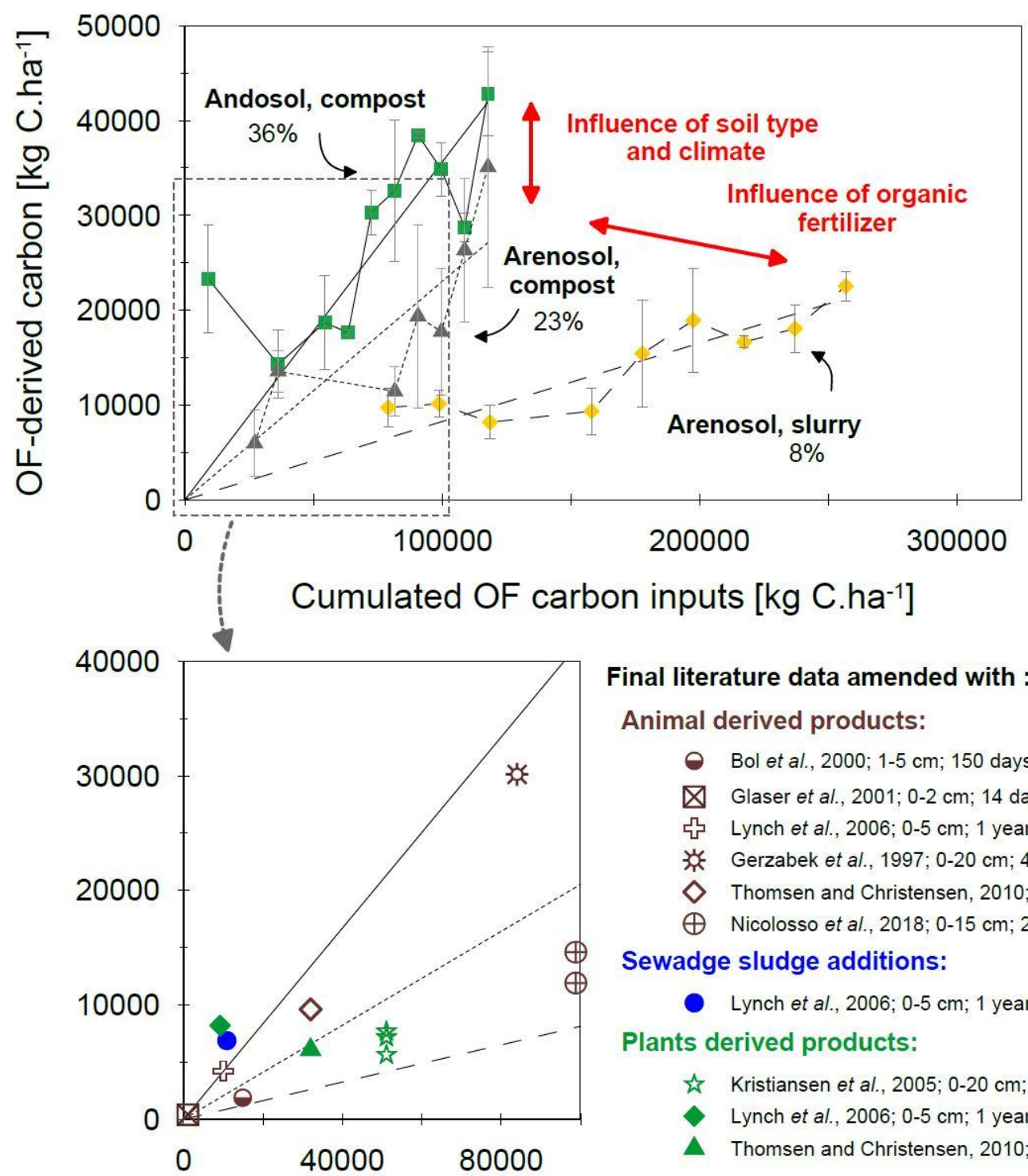

Final literature data amended with :

Animal derived products:

- Bol et al., 2000; $1-5 \mathrm{~cm} ; 150$ days

$\triangle$ Glaser et al., 2001; 0-2 cm; 14 days

ङ Lynch et al., 2006; 0-5 cm; 1 year

Gerzabek et al., 1997; 0-20 cm; 42 years

$\checkmark$ Thomsen and Christensen, 2010;0-20 cm; 9 years

$\bigoplus$ Nicolosso et al., 2018; 0-15 cm; 25 years

Sewadge sludge additions:

Lynch et al., 2006; 0-5 cm; 1 year

Plants derived products:

t) Kristiansen et al., 2005; 0-20 cm; 14 years

Lynch et al., 2006; 0-5 cm; 1 year

- Thomsen and Christensen, 2010;0-20 cm; 9 years 
664 Table S1. Percentage of OF-C according to the methods, i.e. differential, synchronic isotopic and

665 asynchronic isotopic. Mean of three OF-C estimations \pm standard deviation (only two blocks in year 6663 for the Arenosol and year 10 for the Andosol).

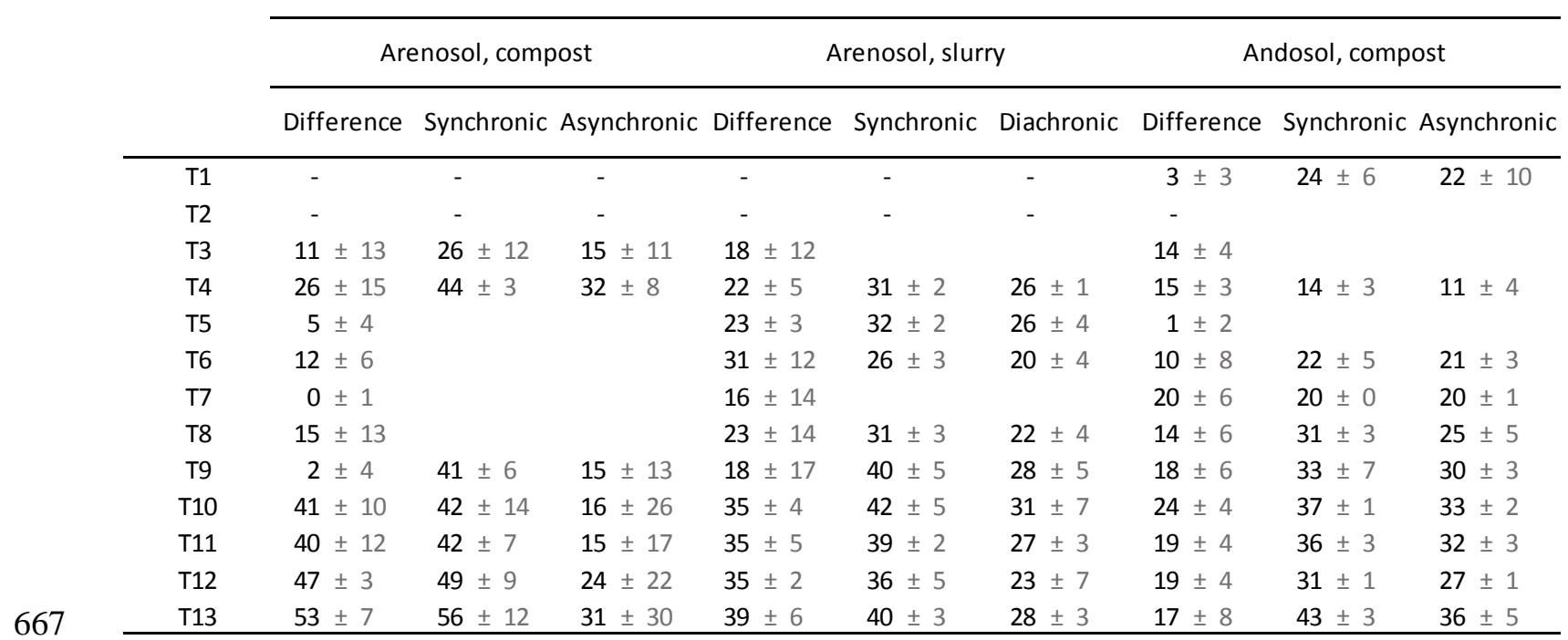


669 Average $\delta^{13} \mathrm{C}$ is the average $\delta^{13} \mathrm{C}$ from three plots at T13. The variation is the standard deviation 670 divided by the average. Importance variable method detailed in part 2.8 .

671

\begin{tabular}{ccccc} 
& Equation variable & $\begin{array}{c}\text { Average } \\
\delta^{13} \mathrm{C}\end{array}$ & $\begin{array}{c}\text { Variation } \\
{[\%]}\end{array}$ & $\begin{array}{c}\text { Weight of the } \\
\text { variable [\%] }\end{array}$ \\
\hline \multirow{3}{*}{ Arenosol compost } & $\delta^{13} \mathrm{C}_{\mathrm{OF}}$ & -20.33 & 14 & 95 \\
& $\delta^{13} \mathrm{C}_{\mathrm{OFsoil}}$ & -18.45 & 2 & 5 \\
& $\delta^{13} \mathrm{C}_{\mathrm{CTRLsoil}}$ & -16.02 & 3 & 1 \\
\hline \multirow{3}{*}{ Arenosol slurry } & $\delta^{13} \mathrm{C}_{\mathrm{OF}}$ & -24.35 & 6 & 58 \\
& $\delta^{13} \mathrm{C}_{\mathrm{OFsoil}}$ & -19.37 & 2 & 26 \\
& $\delta^{13} \mathrm{C}_{\mathrm{CTRLSoil}}$ & -16.02 & 3 & 16 \\
\hline \multirow{3}{*}{ Andosol compost } & $\delta^{13} \mathrm{C}_{\mathrm{OF}}$ & -20.33 & 14 & 92 \\
& $\delta^{13} \mathrm{C}_{\mathrm{OFsoil}}$ & -22.75 & 1 & 6 \\
& $\delta^{13} \mathrm{C}_{\mathrm{CTRLsoil}}$ & -24.58 & 2 & 2 \\
\hline
\end{tabular}


672 Figure S1. Schematic representation of the experimental design of Arenosol and Andosol trials.

673 Consisting of nine plots divided into three blocks with three different treatments, leading to three plots 674 per modality. The plots were randomly distributed within each block.

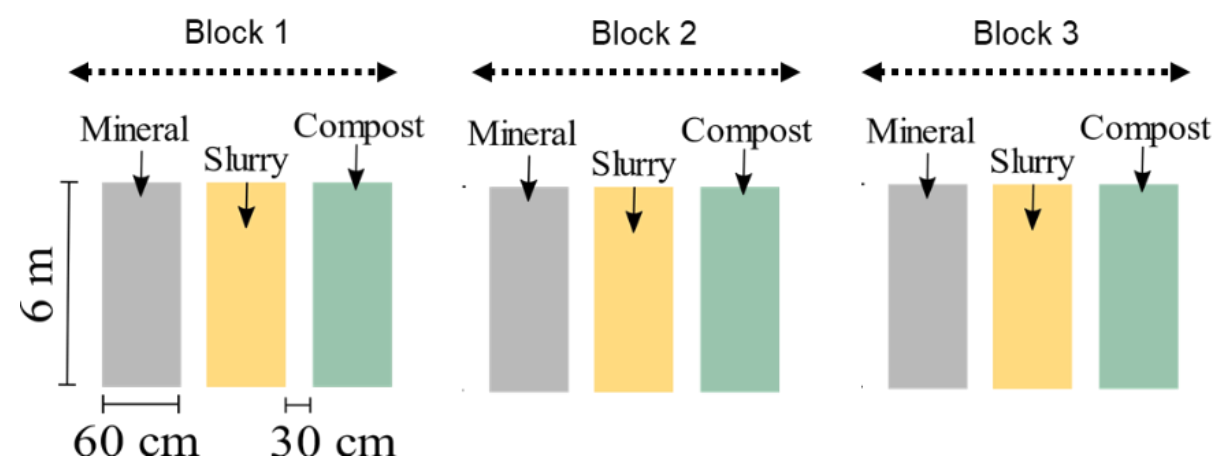



carbon content. Note that a linear regressions on the total carbon from Figure 4 data was done to fit Alexander's law by the least squared method with measurements performed on the Arenosol (5-10 $\mathrm{cm})$ in year 0 an year 14 and on the Andosol $(0-10 \mathrm{~cm})$ in year 3 and 16. Alexander coefficients

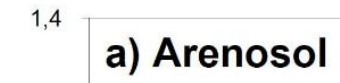

683

684

685

686

687

688

\section{a) Arenosol}

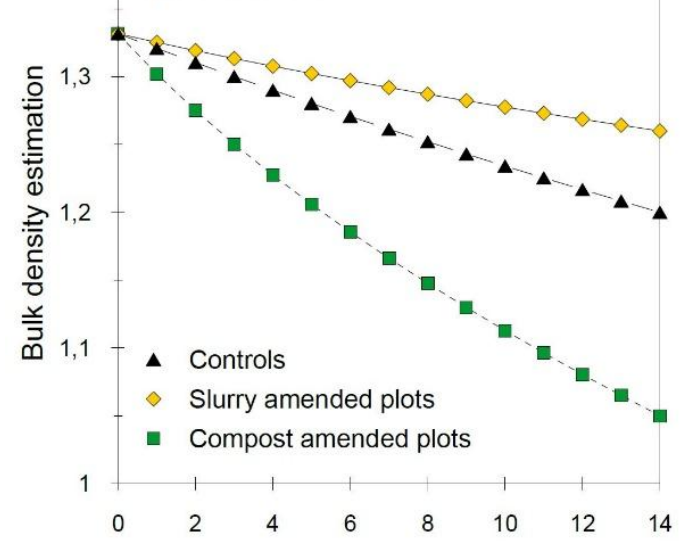

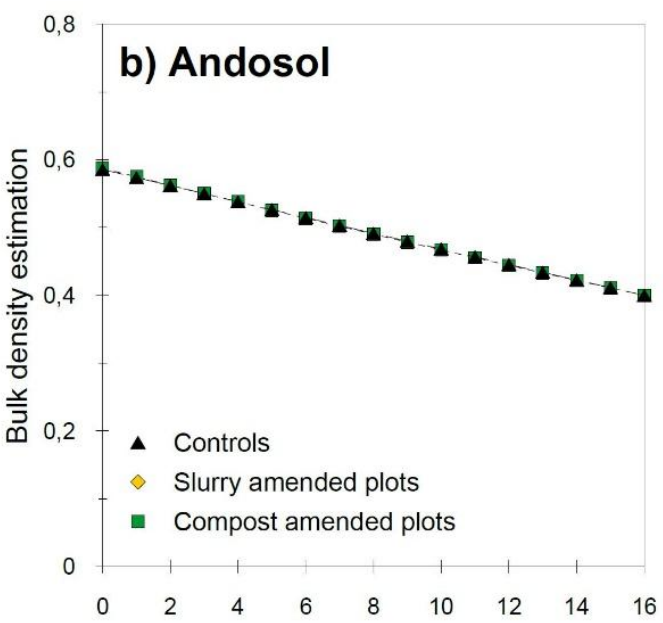

\begin{tabular}{|c|c|c|c|c|c|}
\multicolumn{2}{|c}{ Time after experimentation start [yr] } & \multicolumn{3}{c|}{ Time after experimentation start [yr] } \\
\hline & Controls & $\begin{array}{c}\text { Compost } \\
\text { amended soils }\end{array}$ & $\begin{array}{c}\text { Slurry } \\
\text { amended soils }\end{array}$ & Controls & $\begin{array}{c}\text { Compost } \\
\text { amended soils }\end{array}$ \\
\hline $\begin{array}{c}\text { Alexander's } \\
\text { coefficient } \\
\left(A_{\text {coef }}\right)\end{array}$ & 1.74 & 1.58 & 1.46 & 3.61 & 1.71 \\
\hline Slope $\left(A_{\text {slope }}\right)$ & 0.13 & 0.09 & 0.04 & 0.30 & 0.11 \\
\hline
\end{tabular}


689 Figure S3, OF- $\delta^{13} \mathrm{C}$ over time from years 2 to 9 for the bovine manure compost (green square) 690 and bovine slurry (yellow dot) treatments.

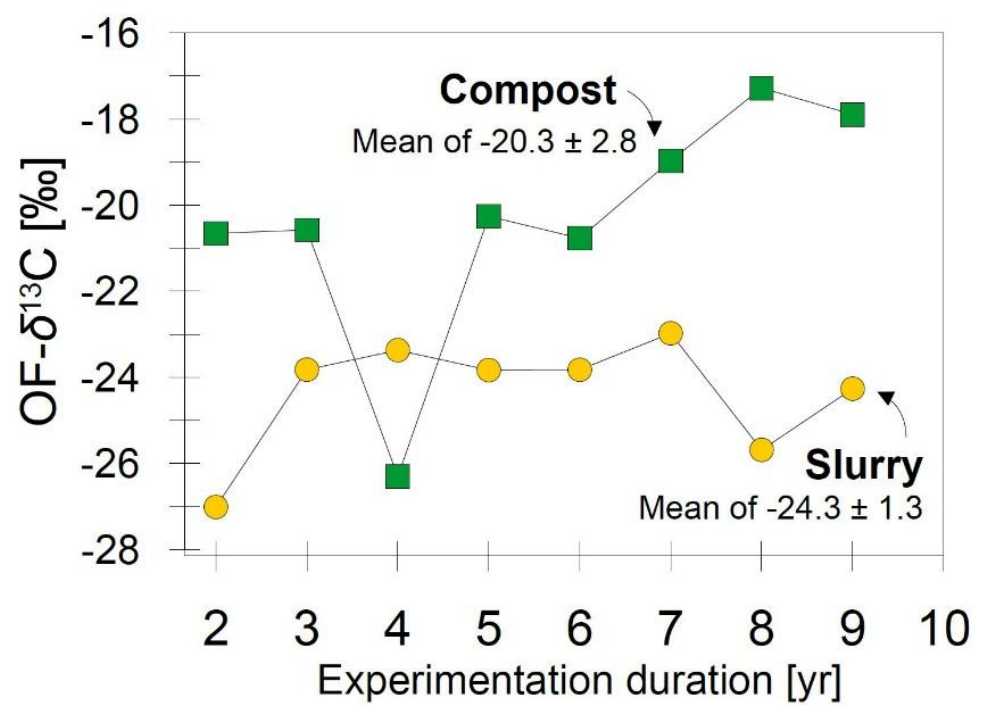

